\title{
THE EMPLOYMENT EFFECTS OF TECHNOLOGICAL INNOVATION, CONSUMPTION, AND PARTICIPATION IN GLOBAL VALUE CHAINS: EVIDENCE FROM DEVELOPING ASIA
}

Donald Jay Bertulfo, Elisabetta Gentile, and Gaaitzen J. de Vries

NO. 572

February 2019
ADB ECONOMICS WORKING PAPER SERIES 


\section{The Employment Effects of Technological Innovation, Consumption, and Participation in Global Value Chains: Evidence from Developing Asia}

Donald Jay Bertulfo, Elisabetta Gentile, and Gaaitzen J. de Vries

No. 572 | February 2019
Donald Jay Bertulfo (dbertulfo.consultant@adb.org) is a consultant and Elisabetta Gentile (egentile@adb.org) is an economist in the Economic Research and Regional Cooperation Department, Asian Development Bank (ADB). Gaaitzen J. de Vries (g.j.de.vries@rug.nl) is an associate professor in the Department of Global Economics and Management, University of Groningen.

This study wouldn't have been possible without the support and enthusiasm of Joseph Mariasingham and the ADB Multiregional Input-Output Table team, as well as the Asian Development Outlook 2018 team, including Rana Hasan; Sameer Khatiwada; Valerie MercerBlackman; Rhea Molato; Rhommell Rico; Joseph Ernest Zveglich, Jr.; and Mia Kim Veloso. We thank all colleagues who offered help and advice, including Abdul Abiad, Jesus Felipe, Anna Fink, and Yasuyuki Sawada. We also thank seminar attendees at ADB and the University of International Business and Economics (UIBE); and conference participants at the 2018 Jobs and Development Conference, the XXX Villa Mondragone International Economic Seminar, the 2018 SCMAP Supply Chain Conference, the 43rd Conference of the Federation of ASEAN Economic Associations, and the Asian and Australasian Society of Labour Economics 2018 Conference. 
(C) 2019 Asian Development Bank

6 ADB Avenue, Mandaluyong City, 1550 Metro Manila, Philippines

Tel +632632 4444; Fax +6326362444

www.adb.org

Some rights reserved. Published in 2019.

ISSN 2313-6537 (print), 2313-6545 (electronic)

Publication Stock No. WPS190022-2

DOI: http://dx.doi.org/10.22617/WPS190022-2

The views expressed in this publication are those of the authors and do not necessarily reflect the views and policies of the Asian Development Bank (ADB) or its Board of Governors or the governments they represent.

ADB does not guarantee the accuracy of the data included in this publication and accepts no responsibility for any consequence of their use. The mention of specific companies or products of manufacturers does not imply that they are endorsed or recommended by ADB in preference to others of a similar nature that are not mentioned.

By making any designation of or reference to a particular territory or geographic area, or by using the term "country" in this document, $A D B$ does not intend to make any judgments as to the legal or other status of any territory or area.

This work is available under the Creative Commons Attribution 3.0 IGO license (CC BY 3.0 IGO)

https://creativecommons.org/licenses/by/3.0/igo/. By using the content of this publication, you agree to be bound by the terms of this license. For attribution, translations, adaptations, and permissions, please read the provisions and terms of use at https://www.adb.org/terms-use\#openaccess.

This CC license does not apply to non-ADB copyright materials in this publication. If the material is attributed to another source, please contact the copyright owner or publisher of that source for permission to reproduce it. $\mathrm{ADB}$ cannot be held liable for any claims that arise as a result of your use of the material.

Please contact pubsmarketing@adb.org if you have questions or comments with respect to content, or if you wish to obtain copyright permission for your intended use that does not fall within these terms, or for permission to use the ADB logo.

Corrigenda to ADB publications may be found at http://www.adb.org/publications/corrigenda.

Notes:

In this publication, “\$” refers to United States dollars.

ADB recognizes "China" as the People's Republic of China and "Korea" as the Republic of Korea.

The ADB Economics Working Paper Series presents data, information, and/or findings from ongoing research and studies to encourage exchange of ideas and to elicit comment and feedback about development issues in Asia and the Pacific. Since papers in this series are intended for quick and easy dissemination, the content may or may not be fully edited and may later be modified for final publication. 


\section{CONTENTS}

TABLES AND FIGURES

ABSTRACT V v

$\begin{array}{ll}\text { I. INTRODUCTION } & 1\end{array}$

II. EVIDENCE FROM THE LITERATURE 3

III. METHODOLOGY

$\begin{array}{llr}\text { IV. DATA } & 10\end{array}$

V. RESULTS $\quad 12$

A. Total Sectoral Employment $\quad 12$

B. The Demand for Routine and Nonroutine Jobs $\quad 15$

C. Foreign versus Domestic Expenditure and Labor Demand 22

VI. CONCLUSION

$\begin{array}{ll}\text { APPENDIX } & 25\end{array}$

$\begin{array}{lr}\text { REFERENCES } & 29\end{array}$ 


\section{TABLES AND FIGURES}

\section{TABLES}

$1 \quad$ Classification of Occupations 11

2 Structural Decomposition Analysis of the Changes in Employment by Sector, 2005-2015 13

3 Structural Decomposition Analysis of the Change in Manufacturing Employment 16 by Occupation Type, 2005-2015

4 Structural Decomposition Analysis of the Change in Services Employment 19 by Occupation Type, 2005-2015

A.1 The 48 Multiregional Input-Output Table Economies 25

A.2 The 35 Multiregional Input-Output Table Industries 26

A.3 Sources of Occupational Employment Data 27

\section{FIGURES}

1 Decomposing Changes in Labor Demand 2

2 The Structure of a Multiregional Input-Output Table 6

3 Changes in the Number of Jobs Induced by Foreign and Domestic Demand, 2005-2015 23 


\begin{abstract}
Global value chains (GVCs) have been a vehicle for job creation in developing Asia, but there is mounting concern that more sophisticated and cost-effective technology could displace workers through automation or reshoring of production. We use the demand-based input-output approach in Reijnders and de Vries (2018) to examine how employment responded to consumption, trade, and technological advances in 12 economies that accounted for $90 \%$ of employment in developing Asia during the period 2005-2015. Structural decomposition analysis based on the Asian Development Bank Multiregional Input-Output Tables combined with harmonized cross-country occupation data indicates that, other things being equal, technological change within GVCs was associated with a decrease in labor demand across all sectors, and an increase in the share of nonroutine cognitive occupations. We also find that increased domestic consumption expenditures of goods and services generated an increase in labor demand large enough to offset the negative employment impact of technological change. Finally, we do not find evidence of major shifts in occupational labor demand due to reshoring.
\end{abstract}

Keywords: developing Asia, employment, global value chains, reshoring, task relocation, technology

JEL codes: D57, F63, J21, O14 


\section{INTRODUCTION}

Between 2005 and 2015, Asia lifted 611 million people out of poverty, bringing down the headcount ratio from 25.6\% to 7\% (ADB 2017). In 2015, developing Asia's share of the developing world's poor stood at $36.2 \%$, which is substantially lower than its share in population and shows an impressive performance since 2005, when Asia accounted for $65 \%$ of the developing world's poor. Participation in global value chains (GVCs) has been an important part of this success story. In 2016, Asia's GVC participation, approximated by the share of value added to gross exports that is used for further processing in cross-border production networks, was 61.1\% (ADB 2017). This was second only to the European Union.

At the micro level, GVC participation has increased productivity of participating firms and provided opportunities for creation of better paid and higher-skilled jobs; at the macro level, it has been associated with enhanced economic growth and higher income per capita (UNESCAP 2015). However, Asian economies at different stages of development have engaged with GVCs in different ways. On one end of the spectrum are the high-income economies that tend to specialize in the knowledge-intensive tasks on the value chain. On the other end of the spectrum are the low-income economies whose firms specialize in tasks that rely on low-skilled labor, resulting in limited opportunities to benefit from technology diffusion and skills upgrading.

While the academic and policy debates have often focused on how to foster developing economies' participation into GVCs and move up the value chain, a new challenge is on the horizon. As Fourth Industrial Revolution (4IR) technologies such as digital manufacturing become more sophisticated and more effective, there is a risk that their adoption may result in job losses in developing Asia (ADB 2018). There are substantially two mechanisms through which this could happen. First, if machines replace workers at one or more of the production tasks in the GVC, this will lower the number of jobs in the GVC needed to meet given demand. Second, the growing use of 4IR technologies may erode the labor cost advantage of emerging countries by making labor costs a smaller share of total costs, thus encouraging reshoring production to advanced economies (De Backer et al. 2016).

Furthermore, to the extent that the technologies of the 4IR are skill biased, their adoption may shift demand from workers with lower skills to those with higher skills, thus widening inequality. This poses a problem for developing economies competitive in low- to medium-skill tasks, as using advanced technologies could create a shortage of high-skilled workers and a surplus of medium- and low-skilled workers.

Understanding how 4IR technologies will affect employment along the value chain in developing Asia is as important as it is challenging. The first challenge relates to investigating a process that is only starting: a forecasting exercise requires heavy assumptions, and the results are quite sensitive to those assumptions. An additional challenge is that data on investment in new technologies in Asian economies are not as readily available. Finally, the location of a production task and technology adoption are not independent decisions, and their effect on the broader economy depends on the degree of exposure to a specific GVC.

In this paper, we uncover the impacts of $4 I R$ technologies on jobs in developing Asia in the past decade. Our approach is to apply the structural decomposition analysis (SDA) framework developed in Reijnders and de Vries (2018) to the Asian Development Bank (ADB) Multiregional Input-Output Tables (MRIOTs) to examine the relationship between technology and jobs along value 
chains in 12 economies in developing Asia, covering 35 sectors from 2005 to 2015. The 12 economies accounted for $90 \%$ of employment in developing Asia in 2015. The analytical framework in Reijnders and de Vries (2018) has two important advantages: it allows for macroeconomic analysis of GVCs and adheres to national account series of gross output, value added, and employment. The rapid decline in the price of robots has led to increased use of robots across industries (Graetz and Michaels 2018). By 2005, the price of robots (adjusted for quality) was about one-fifth of their price in 1990 (Graetz and Michaels 2018). The resulting rapid increase and widespread adoption of robots since the mid-2000s, has guided us in studying recent changes in the structure of employment.

The decomposition of the change in an economy's number of jobs from 2005 to 2015 occurs on two levels (Figure 1). At the first level, the change in employment is decomposed into change within the GVC, or changes in employment within the production structure or GVC of a specific final product, and change between GVCs, or changes in employment resulting from shifts in consumer demand for different products. Finally, "consumption levels" refer to changes in employment associated with changes in global demand for goods and services. In practice, higher consumption levels will increase demand for goods and services, which in turn will increase employment.

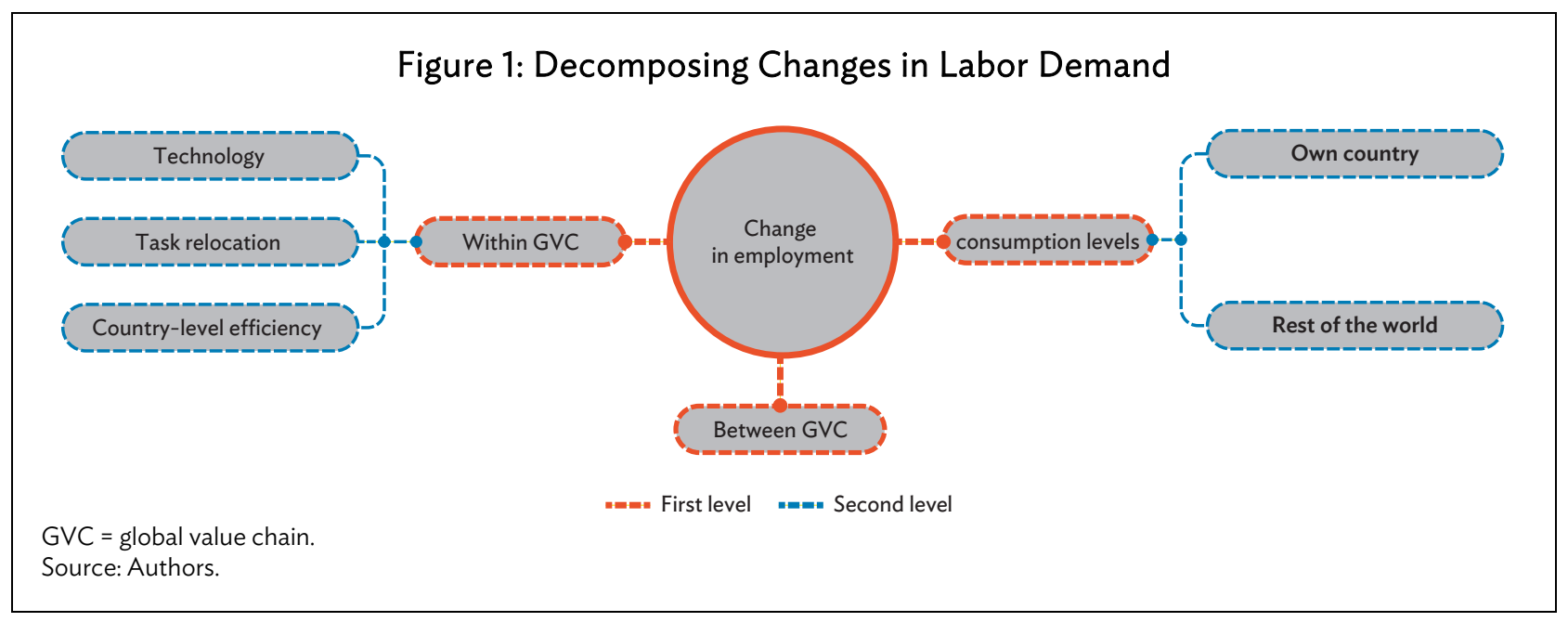

The SDA further decomposes the within-GVC channel into (i) technology within the GVC, or changes in employment associated with changes in efficiency within a specific GVC; (ii) task relocation, or changes in employment as the location changes for one production task or more; and (iii) country-level efficiency, or changes in employment from efficiency changes in the economy. Consumption levels are further decomposed into "own country," or demand for goods and services originating within a specific country, and "rest of the world," or demand from abroad for goods and services. The purpose is to see what fraction of employment depends on domestic demand and what fraction on foreign demand.

To preview our results, we have three key findings. First, our analysis indicates that technological advances along the value chain are associated with a decrease in the levels of employment in both routine and nonroutine occupations. Many Asian developing member countries (DMCs) benefited from the relocation of GVC tasks to their economies, but the effects of technological change account for a larger change in labor demand compared to task relocation. Second, we document that rising demand for goods and services finalized and consumed in the 12 Asian DMCs covered in the analysis induced an 11\% increase in jobs within the region, suggestive of a rebalancing away from a manufacturing and export-led growth model, to services and consumption- 
led model. Moreover, the increases in employment associated with consumption levels domestically and in the rest of the world are large enough to offset the decrease in employment associated with technology within GVCs. Third, our results show that in eight out of the 12 developing Asian economies that we study, there has been a rise in nonroutine jobs during the past decades. In India; Indonesia; Malaysia; Mongolia; the People's Republic of China (PRC); the Philippines; the Republic of Korea; and Taipei,China, growth in nonroutine jobs was faster compared to the growth in routine jobs.

It is helpful to place our paper in a broader context. There are several closely related empirical studies that juxtapose the role of technology and trade in explaining job polarization. For example, Autor, Dorn and Hanson (2016) exploit initial differences in exposure to Chinese competition across local labor markets in the United States (US) to explain subsequent changes in the employment structure. They find that import competition and technological change reduce demand for routine production and clerical occupations relative to those that are intensive in abstract tasks (such as professionals and managers) and manual tasks (such as personal services). Other related studies include Goos, Manning, and Salomons (2014) and Reijnders, Timmer and Ye (2016). But these studies focus on advanced countries and several emerging countries. In contrast, this paper examines the drivers of labor demand in developing Asian countries.

The empirical concept of a GVC that we employ in this paper is based on Timmer et al. (2014) and consists of all activities that are directly or indirectly needed to produce a product that is used for final consumption. An example of a GVC is the production of garments that have their final assembly stage in Bangladesh (an example we will use throughout this paper), but with many of the inputs sourced from other countries. Developing countries in Asia are at different levels of development and differ in terms of their integration in GVCs. Moreover, it is likely that the impact of new technologies on labor demand differs between advanced and developing countries due to lower wages in developing Asia and hence less incentives to substitute automation for labor input. This makes it interesting to study the relation between technology, trade, and rising consumer expenditures in driving labor demand in Asian countries.

The rest of this paper is structured as follows: section II provides an overview of the existing empirical literature, section III presents the methodology, section IV describes the data, and section $V$ discusses our findings. Finally, section VI concludes with a discussion of the implications of our results, as well as potential avenues for future research.

\section{EVIDENCE FROM THE LITERATURE}

The impact of technology on employment has been studied since the early 19th century, when the first generation of workers had the experience of being suddenly displaced by automation. Historically, the displacement has disproportionally affected workers on the lower end of the skill distribution, as machines could undertake mostly simple, repetitive tasks. But the technologies of the 4IR are characterized by the convergence of a wide range of breakthroughs in the digital, physical, and biological sphere that are increasingly encroaching on high-skill occupations.

In this section, we discuss three different approaches to studying the relationship between technology and jobs. The first approach investigates how feasible it is to automate existing jobs given current and presumed technological advances. Frey and Osborne (2017) is the first of such feasibility 
studies, and their findings had a big impact. 'They predicted that 47\% of total US-based employment is at high risk of automation, with office and administrative support, sales, and other mostly middleskilled service occupations taking the biggest hit. Their "occupation-based approach" links the O*NET database, which contains survey-based information on the task content of each occupation, with 2010 employment and wage data from the U.S. Bureau of Labor Statistics, creating a dataset that distinguishes 702 occupations. With a group of machine learning researchers, they label 70 occupations as automatable or not, and then they use a Gaussian process classifier to predict the probability of automation for the remaining 632, based on the features of the 70 occupations. They then distinguish between high (greater than 0.7), medium (between 0.3 and 0.7) and low (less than 0.3) risk of automation. Using the methodology from Frey and Osborne (2017), Chang and Huynh (2016) study the impact of technologies on employment in Cambodia, Indonesia, the Philippines, Thailand, and Viet Nam, and conclude that up to $56 \%$ of all employment in these countries is at risk of displacement due to technology over the next decade or 2.

This "occupation-based approach" has several shortcomings. First, automation does not target entire occupations, but specific tasks within an occupation. Second, the automation of one or more tasks in an occupation may be technically but not economically feasible. Third, even if it is both technically and economically feasible to automate one or more tasks, workers can adapt to the new division of labor by switching tasks. Furthermore, 4IR technologies, as with past technologies, could be complementary to workers, enabling them to increase productivity, leading to higher wages within sectors and productivity spillovers to other industries. This can support general economic and employment growth. Finally, by using Frey and Osborne data on the probability of automation in the US, Chang and Huynh (2016) assume that the task contents for each occupation are similar across countries. These shortcomings suggest the occupation-based approach by Frey and Osborne (2017) may seriously overestimate the risk of automation for entire occupations.

Arntz, Gregory, and Zierahn (2016) take a "task-based approach" to estimate the susceptibility of employment to automation for 21 Organisation for Economic Co-operation and Development (OECD) countries. They use individual survey data from the Programme for the International Assessment of Adult Competencies, which provides a list of tasks people actually perform at their workplace. They find that only $9 \%$ of jobs in the US are at high risk of automation, compared with the 47\% estimated by Frey and Osborne (2017). This task-based approach has some of the same faults as the occupation-based approach: it is still based on technical feasibility rather than actual adoption of new technologies, and it does not consider whether workers adapt to the new division of labor. Furthermore, it only analyzes existing occupations when new technologies tend to create new jobs (Stewart, Debapratim, and Cole 2015). Nonetheless, task-based approaches show that the technical automation of jobs may be lower than feared under occupation-based approaches-and these estimates do not consider economic feasibility and potential productivity gains.

An additional reason why the impact of 4IR technologies in developing Asia may not be as severe is that the region continues to undergo structural transformation-a movement of employment from mostly low-productivity, low-paying jobs in agriculture to higher-productivity, better-paying jobs in industry and services, expanding the middle class and stimulating final demand. Developing Asia has created 30 million nonagricultural jobs annually over the past 25 years (ADB 2018) partly due to structural transformation, as well as technology-driven improvements in productivity.

Several studies adapt (or build on) their methodology. See, for example, Chang and Huynh (2016), MGI (2017), Citi and Oxford Martin School (2016). 
A second line of research estimates the effect of the increased use of a specific technology on employment, wages, and the broader economy. Such studies focus mostly on advanced economies, because they require a wealth of data generally unavailable for developing economies. While some insightful studies focus on the impact of information and communication technologies on employment (see, for example, Autor, Levy, and Murnane [2003]; Michaels, Natraj, and Van Reenen [2014]; and Chun and Tang [2018]), industrial robots are the technology that perhaps best embodies the 4IR, because of their capacity for autonomous movement and ability to perform an expanding set of tasks.

Acemoglu and Restrepo (2017) estimate the effect of the increase in industrial robot usage between 1990 and 2007 on employment and wages in US local labor markets, which they proxy by commuting zones. They regress the change in employment and wages on the exposure to robotsdefined as the sum over industries of the national penetration of robots into each industry times the baseline employment share of that industry in the labor market-and find large and robust negative effects of robots on employment and wages across commuting zones. When they incorporate trade between commuting zones, allowing the productivity gains from robot usage to spill over to other community zones, they find smaller negative employment effects and considerably smaller negative wage effects from robots.

Graetz and Michaels (2018) use an instrumental variables approach to estimate the effect of robot adoption within industries in 17 OECD countries during 1993-2007. They find that increased robot use contributed approximately 0.36 percentage points to annual labor productivity growth, while at the same time raising total factor productivity and lowering output prices. Interestingly, their estimates suggest that robots did not significantly reduce total employment, although they did reduce the employment share of low-skilled workers.

Finally, a branch of the literature uses measures of productivity growth that vary across industries as an all-encompassing proxy for the effects of technological progress. This approach bypasses the formidable difficulty of examining the employment implications of specific technological innovations.

Autor and Salomons (2017) explore the relationship between productivity growth and employment using country- and industry-level data for 19 OECD countries over 37 years. They find a significant decrease in industry-level employment as industry productivity rises, implying that technically progressive sectors tend to shrink. However, the negative own-industry employment effect of rising productivity is outweighed by positive spillovers to the rest of the economy, so that countrylevel employment generally grows as aggregate productivity rises.

Reijnders and de Vries (2018) use the World Input-Output Database (WIOD) to perform a structural decomposition analysis of the changes in the employment share of nonroutine jobs due to technological change and task relocation for a group of 40 advanced and emerging economies between 1999 and 2007. They find that technological change increased the number of nonroutine relative to routine jobs in all countries, and task relocation, albeit less strong, works in the same direction for advanced countries, but in the opposite direction for emerging countries.

In sum, the existing literature finds that technology affects both the level and the composition of employment: increased use of technology leads to a decrease in overall employment, but occupations traditionally considered low and middle skill are more affected. However, these studies focus on advanced (and a few emerging) economies. Therefore, we contribute to the literature by adopting the methodology in Reijnders and de Vries (2018) to investigate the relationship between technology and jobs in developing Asia. 


\section{METHODOLOGY}

In the framework adopted here, the use of labor inputs is driven by demand. The production process of GVCs is modeled as consisting of different tasks. This aligns with the 'task approach to labor markets' (Autor 2013), which enables an analysis of the interactions among technological capabilities, trade, and offshoring opportunities, as well as quantification of the effects of these forces on labor demand. Reijnders and de Vries (2018) introduce a methodological innovation by linking this task approach to the Leontief input-output framework extended to a multicountry setting, which makes it possible to decompose changes in occupational labor demand into its several components.

In our task-based framework, task outputs are produced using production factors (capital and labor), which are sourced either domestically or from foreign suppliers. As in Goos, Manning, and Salomons (2014), we assume that there is a one-to-one mapping between occupations and tasks, so that each task requires labor of a certain occupation and each occupation only performs that specific task. We also assume that tasks along a GVC are perfect complements, i.e., a fixed amount of each task (or occupational input) is required in the production of a final product. ${ }^{2}$ Task outputs can either be sold to final consumers or be used as an input to production (at home or abroad).

We start by assuming that there are $G$ countries and $N$ industries within each country. We follow Timmer et al. (2014) and define a GVC as a country-industry pair that delivers a product for final use. ${ }^{3}$ The basic structure of the ADB MRIOTs (augmented with employment per countryindustry) for a given year is shown in Figure 2.

Figure 2: The Structure of a Multiregional Input-Output Table

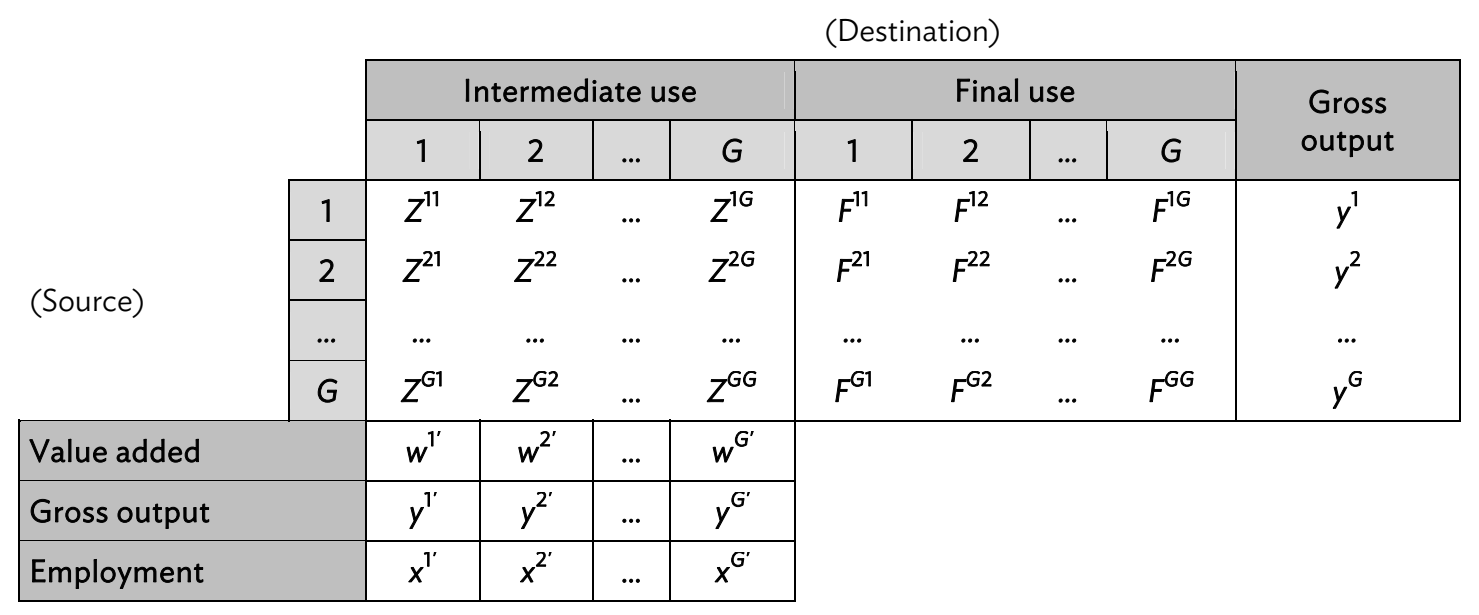

Source: ADB Multiregional Input-Output Database.

2 Modeling task inputs as perfect complements in production implies that the task production functions in this empirical analysis admits the Leontief (fixed proportions) functional form (Miller and Blair 2009).

3 We use the term country-industry to mean an industry in a particular country, such as the Bangladesh textiles industry or the Japanese electronics industry. 
For ease of exposition, we formally define source and destination countries and source and destination industries. In particular, we let $i$ be the index for the source industry, $j$ the destination industry, $r$ the source country, and $s$ the destination country. The $G N x G N$-matrix $\mathbf{Z}=\left[Z^{r s}\right]=$ $\left[\begin{array}{ccc}Z^{11} & \ldots & Z^{1 G} \\ \vdots & \ddots & \vdots \\ Z^{G 1} & \ldots & Z^{G G}\end{array}\right]$ records the flows of outputs for intermediate use between industries worldwide. $Z^{r s}$ is an $N x N$ block matrix whose typical element $z_{i j}^{r s}$ gives the dollar value of output from industry $i$ in country $r$ used as intermediate inputs to production in industry $j$ of country s. The GNxGP matrix $\mathbf{F}=\left[\boldsymbol{F}^{\mathbf{r s}}\right]=\left[\begin{array}{ccc}\boldsymbol{F}^{11} & \ldots & \boldsymbol{F}^{\mathbf{1 G}} \\ \vdots & \ddots & \vdots \\ F^{G 1} & \ldots & F^{G G}\end{array}\right]$ of final demand contains, for each country-industry, the output for final use in every country. ${ }^{4} \boldsymbol{F}^{\boldsymbol{r} s}$ is an NxP matrix whose typical element $f_{i p}^{r s}$ gives the dollar value of output from industry $i$ in country $r$ used to satisfy final demand (in category $p$ ) in country s. Gross output and value added per country-industry pair are stored in the GNx1 vectors $\mathbf{y}=\left[\begin{array}{c}\boldsymbol{y}^{\mathbf{1}} \\ \vdots \\ \boldsymbol{y}^{G}\end{array}\right]$ and $\mathbf{w}=\left[\begin{array}{c}\boldsymbol{w}^{\mathbf{1}} \\ \vdots \\ w^{G}\end{array}\right]$, respectively. Each element of $\boldsymbol{y}^{\boldsymbol{r}}$ describes the gross output of each industry in country $r$ while each element of $\boldsymbol{w}^{\boldsymbol{s}}$ indicates the value added generated by each industry in country $\boldsymbol{s}$ throughout the entire production process.

Market-clearing conditions imply that total output of a particular country-industry must tally with its total (i.e., intermediate and final) use domestically and globally. Therefore, the fundamental relationship between matrices $\mathbf{Z}, \mathbf{F}$, and $\mathbf{y}$ is given by the following equation:

$$
\mathbf{y}=\mathbf{Z} \mathbf{1}_{G N, 1}+\mathbf{F} \mathbf{1}_{G P, 1}
$$

where $\mathbf{1}_{\alpha, 1}$ is a vector of 1s with length $\alpha$. Put simply, the gross output vector $\mathbf{y}$ can be obtained from adding the row-sums of matrices $\mathbf{Z}$ and $\mathbf{F}$.

We use this data to construct two new matrices. The first one is $\mathbf{A}=\mathbf{Z} \hat{\mathbf{y}}^{\mathbf{- 1}}$, the $G N \times G N$ matrix of intermediate use coefficients. ${ }^{5} \mathrm{~A}$ typical element of $\mathbf{A}, a_{i j}^{r s}$, refers to the dollar value of the intermediate inputs of industry $i$ in country $r$ per dollar of output of industry $j$ in country $s$. Second, we add up across final demand categories and countries to derive the $G N \times 1$ vector $\mathbf{f} \equiv \mathbf{F} \mathbf{1}_{G P, 1}$. Using these two new matrices, we rewrite (1) as:

$$
\mathbf{y}=\mathbf{A y}+\mathbf{f}
$$

Solving for $\mathbf{y}$, we obtain the fundamental identity by Leontief (1936):

$$
\mathbf{y}=\mathbf{B f}
$$

where $\mathbf{B}=\left(\mathbf{I}_{\boldsymbol{G N}}-\mathbf{A}\right)^{\mathbf{- 1}}$ is the so-called global Leontief inverse. Here, $\mathbf{I}_{\boldsymbol{G N}}$ stands for the $G N \times G N$ identity matrix. A given column of $\mathbf{B}$ contains the dollar value of output of all industries and all countries required to produce one dollar of final output for the corresponding country-industry pair.

\footnotetext{
4 Here we represent final demand as consisting of $P$ categories, which can include final expenditure for consumption, government, and investment, as well as inventories.

5 A hat (e.g., $\hat{\mathbf{y}}$ ) indicates a diagonal matrix, with the elements of the vector $\mathbf{y}$ on the diagonal.
} 
Moving from output to occupational employment requires that we model the production process more explicitly. We can define $l_{k i}^{r}$ as the quantity of employment in occupation $k$ per unit of output in industry $i$ of country $r: l_{k i}^{r}=x_{k i}^{r} / y_{i}^{r}$ and then create the $G N$-column vector $\boldsymbol{l}_{\mathbf{k}}$. We define another vector $\mathbf{x}_{\mathbf{k}}$ which contains, for each country-industry pair, demand for labor in occupation $k$ in all stages of production of final products by GVCs worldwide:

$$
\mathbf{x}_{\mathbf{k}}=\hat{\boldsymbol{l}}_{\mathbf{k}} \mathbf{B f}
$$

where $\hat{\boldsymbol{l}}_{\mathbf{k}}$ is a diagonal matrix containing labor requirements of occupation $k$ per unit of gross output in each of the GN GVCs. A typical element of $\mathbf{x}_{\mathbf{k}}, x_{k i}^{r}$, represents all labor of occupation $k$ from industry $i$ in country $r$ required to satisfy worldwide final demand for goods and services. For instance, an element of $\mathbf{x}_{\mathbf{k}}$ may be all routine manual labor in the Bangladesh textiles industry required to satisfy worldwide final demand. Since routine manual labor in the Bangladesh textiles industry may be contributing to the production of final goods and services in other country-industries (not just Bangladesh textiles alone), all direct and indirect jobs demanded from it are captured in $\mathbf{x}_{\mathbf{k}}$.

To analyze the relative impacts of trade, technology, and consumption levels in occupational labor demand, we further decompose equation (4), see also Los, Timmer, and de Vries (2014). In particular, we follow de Vries et al. (2016) and specify three determinants of intertemporal changes in $\mathbf{x}_{\mathbf{k}}$ that affect the product $\hat{\boldsymbol{l}}_{\mathrm{k}} \mathbf{B}$ and three determinants that affect $\mathbf{f}$. The former set of determinants relate to changes within GVCs, while the latter is associated with changes in the relative weights of GVCs. We can express the employment in occupation $k$ as ${ }^{6}$

$$
\mathbf{x}_{\mathbf{k}}=\widehat{\boldsymbol{\pi}}^{-1} \mathbf{R}_{\mathbf{k}} \hat{l}_{\mathbf{k}}^{*}\left[\mathbf{T}^{*} \circ\left(\mathbf{S}^{*} \cdot \hat{\mathbf{c}}\right)\right] \mathbf{u}
$$

In this equation, $\mathbf{c}$ is a $\mathrm{G}$-vector. Its typical element $c^{s}$ contains total final demand exerted by country $s$ (the destination country). By construction, changes in $\mathbf{c}$ would reflect changes in demand for goods and services finally consumed in country s. $\mathbf{S}^{*}$ is an $G N x G$-matrix constructed by stacking $G$ identical $N \times G$-matrices of final demand shares of each of the $N$ industries. The rows of the $N \times G$ matrices that together form $\mathbf{S}^{*}$ are obtained by aggregating over final goods supplied by each of the trade partners. This matrix describes the relative distribution of final demand use across GVCs worldwide. Thus, changes in this matrix would capture changes in the composition of consumption across GVCs. $\mathbf{T}^{*}$ is an GNxG-matrix of final product trade coefficients. Its typical element $t_{i}^{r s}$ represents the share of country $r$ in final demand for products of industry $i$ in country $s$. Changes in this matrix would reflect changes in the relative share of GVCs in the production of final products. $\mathbf{u}$ is a $G$ elements summation vector consisting of $1 \mathrm{~s}$.

If the production of final products is a fragmented process organized in (global) value chains, the GN-vector $\boldsymbol{I}_{k}{ }^{w^{\prime}} \equiv \boldsymbol{I}_{k}{ }^{\prime} \mathbf{B}$ gives a more appropriate measure of the techniques used to produce final products. ${ }^{7} \boldsymbol{I}_{k}^{w}$ gives the worldwide inputs of occupation $k$ used to produce one unit of output from each of the GN GVCs, irrespective of the location of the activities required. Furthermore, we assume that Hicks-neutral country-level differences in the efficiency with which production factors are employed exist so that countries differ in their manner of transforming inputs to outputs. These Hicksneutral country-level differences are captured in the GN-productivity vector $\boldsymbol{\pi}$ of which a typical

6 The operator $O$ is called the "Hadamard product" in matrix literature. It signifies element-by-element matrix multiplication. If $\mathbf{A}=\left[a_{i j}\right]$ and $\mathbf{B}=\left[b_{i j}\right]$ are matrices of the same size, $\mathbf{A}^{\circ} \mathbf{B}=\left[a_{i j} b_{i j}\right]$ for all $i$ and $j$.

7 A prime $\left({ }^{\prime}\right)$ indicates matrix transposition. For example, if $\mathbf{A}=\left[a_{i j}\right]$ is a matrix, then $\mathbf{A}^{\prime}=\left[a_{j i}\right]$ for all $i$ and $j$. That is, the elements of the rows of $\mathbf{A}^{\prime}$ correspond to the elements of the columns of $\mathbf{A}$. 
element $\pi^{s}$ corresponds to the total factor productivity (TFP) level of country s. To construct $\pi$, we construct a measure of TFP for each country and each year using the Penn World Tables (see section IV). Introducing this efficiency correction term allows us to express the demand by a certain GVC for labor of occupation $k$ in efficiency units, $\boldsymbol{l}_{k}^{* \prime} \equiv\left(\boldsymbol{\pi} \circ \boldsymbol{l}_{k}\right)^{\prime} \mathbf{B}$. This more accurately describes the relative use of task inputs along GVCs.

Since an ADB MRIOT represents $G N$ industries in which labor is employed and $G N$ global value chains to which this labor contributes, we can compute an $G N \times G N$-matrix, $\mathbf{R}_{\mathrm{k}}=\left\{\widehat{\boldsymbol{\pi}} \hat{\boldsymbol{l}}_{\mathbf{k}} \mathbf{B}\right\} \hat{\boldsymbol{l}}_{\mathrm{k}}^{*}{ }^{-1}$, with shares of each of the GN industries to total employment in occupation k per unit of final demand produced. Rows correspond to industries of employment, columns correspond to the GVCs to which labor of type $k$ contributes. Changes in the matrix would reflect relative changes in the use of intermediate inputs by GVCs.

By adding a time element in our framework, we are able to examine the determinants of occupational labor demand between two points in time. In particular, we let $\mathbf{x}_{\mathbf{k} \mathbf{1}}$ and $\mathbf{x}_{\mathbf{k} \mathbf{0}}$ denote employment in occupation $k$ at time 1 and time 0 respectively. Then, the difference between occupational labor demand at two points in time $\left(\mathbf{x}_{\mathbf{k} \mathbf{1}}-\mathbf{x}_{\mathbf{k} \mathbf{0}}\right)$ can be written as

$$
\begin{aligned}
& \mathbf{x}_{\mathbf{k} 1}-\mathbf{x}_{\mathbf{k} 0}=\widehat{\pi}_{\mathbf{1}}^{-1} \mathbf{R}_{\mathbf{k} \mathbf{1}} \hat{l}_{\mathbf{k} \mathbf{1}}^{*}\left[\mathbf{T}_{\mathbf{1}}^{*} \circ\left(\mathbf{S}_{\mathbf{1}}^{*} \cdot \hat{\mathbf{c}}_{\mathbf{1}}\right)\right] \mathbf{u}-\widehat{\boldsymbol{\pi}}_{\mathbf{0}}^{-1} \mathbf{R}_{\mathbf{k} \mathbf{0}} \hat{l}_{\mathbf{k} 0}^{*}\left[\mathbf{T}_{\mathbf{0}}^{*} \circ\left(\mathbf{S}_{\mathbf{0}}^{*} \cdot \hat{\mathbf{c}}_{\mathbf{0}}\right)\right] \mathbf{u}= \\
& \frac{1}{2}\left\{\left\langle\widehat{\pi}_{1}^{-1}-\widehat{\pi}_{\mathbf{0}}^{-1}\right\rangle \mathbf{R}_{\mathbf{k} 1} \hat{l}_{\mathbf{k} 1}^{*}\left[\mathbf{T}_{1}^{*} \circ\left(\mathbf{S}_{1}^{*} \cdot \hat{\mathbf{c}}_{\mathbf{1}}\right)\right] \mathbf{u}+\left\langle\hat{\pi}_{\mathbf{1}}^{-1}-\widehat{\pi}_{\mathbf{0}}^{-1}\right\rangle \mathbf{R}_{\mathbf{k} \mathbf{0}} \hat{l}_{\mathbf{k} 0}^{*}\left[\mathbf{T}_{\mathbf{0}}^{*} \circ\left(\mathbf{S}_{\mathbf{0}}^{*} \cdot \hat{\mathbf{c}}_{\mathbf{0}}\right)\right] \mathbf{u}\right\}+ \\
& \frac{1}{2}\left\{\widehat{\pi}_{\mathbf{0}}^{-1}\left\langle\mathbf{R}_{\mathbf{k} 1}-\mathbf{R}_{\mathbf{k} 0}\right\rangle \hat{l}_{\mathbf{k} 1}^{*}\left[\mathbf{T}_{1}^{*} \circ\left(\mathbf{S}_{\mathbf{1}}^{*} \cdot \hat{\mathbf{c}}_{\mathbf{1}}\right)\right] \mathbf{u}+\widehat{\boldsymbol{\pi}}_{\mathbf{1}}^{-1}\left\langle\mathbf{R}_{\mathbf{k} 1}-\mathbf{R}_{\mathbf{k} 0}\right\rangle \hat{l}_{\mathbf{k} 0}^{*}\left[\mathbf{T}_{\mathbf{0}}^{*} \circ\left(\mathbf{S}_{\mathbf{0}}^{*} \cdot \hat{\mathbf{c}}_{\mathbf{0}}\right)\right] \mathbf{u}\right\}+ \\
& \frac{1}{2}\left\{\widehat{\boldsymbol{\pi}}_{\mathbf{0}}^{-1} \mathbf{R}_{\mathbf{k} \mathbf{0}}\left\langle\hat{l}_{\mathbf{k} \mathbf{1}}^{*}-\hat{\boldsymbol{l}}_{\mathbf{k} \mathbf{0}}^{*}\right\rangle\left[\mathbf{T}_{\mathbf{1}}^{*} \circ\left(\mathbf{S}_{\mathbf{1}}^{*} \cdot \hat{\mathbf{c}}_{\mathbf{1}}\right)\right] \mathbf{u}+\widehat{\boldsymbol{\pi}}_{\mathbf{1}}^{-1} \mathbf{R}_{\mathbf{k} \mathbf{1}}\left\langle\hat{l}_{\mathbf{k} \mathbf{1}}^{*}-\hat{l}_{\mathbf{k} \mathbf{0}}^{*}\right\rangle\left[\mathbf{T}_{\mathbf{0}}^{*} \circ\left(\mathbf{S}_{\mathbf{0}}^{*} \cdot \hat{\mathbf{c}}_{\mathbf{0}}\right)\right] \mathbf{u}\right\}+ \\
& \frac{1}{2}\left\{\widehat{\boldsymbol{\pi}}_{\mathbf{0}}^{-1} \mathbf{R}_{\mathbf{k} \mathbf{0}} \hat{l}_{\mathbf{k} 0}^{*}\left[\left\langle\mathbf{T}_{\mathbf{1}}^{*}-\mathbf{T}_{\mathbf{0}}^{*}\right\rangle_{\circ}\left(\mathbf{S}_{\mathbf{1}}^{*} \cdot \hat{\mathbf{c}}_{\mathbf{1}}\right)\right] \mathbf{u}+\widehat{\boldsymbol{\pi}}_{\mathbf{1}}^{-1} \mathbf{R}_{\mathbf{k} \mathbf{1}} \hat{l}_{\mathbf{k} \mathbf{1}}^{*}\left[\left\langle\mathbf{T}_{\mathbf{1}}^{*}-\mathbf{T}_{\mathbf{0}}^{*}\right\rangle_{\circ}\left(\mathbf{S}_{\mathbf{0}}^{*} \cdot \hat{\mathbf{c}}_{\mathbf{0}}\right)\right] \mathbf{u}\right\}+ \\
& \frac{1}{2}\left\{\widehat{\pi}_{\mathbf{0}}^{-1} \mathbf{R}_{\mathbf{k} 0} \hat{l}_{\mathbf{k} 0}^{*}\left[\mathbf{T}_{\mathbf{0}}^{*} \circ\left(\left\langle\mathbf{S}_{\mathbf{1}}^{*}-\mathbf{S}_{\mathbf{0}}^{*}\right\rangle \cdot \hat{\mathbf{c}}_{\mathbf{1}}\right)\right] \mathbf{u}+\widehat{\boldsymbol{\pi}}_{\mathbf{1}}^{-1} \mathbf{R}_{\mathbf{k} \mathbf{1}} \hat{l}_{\mathbf{k} \mathbf{1}}^{*}\left[\mathbf{T}_{\mathbf{1}}^{*} \circ\left(\left\langle\mathbf{S}_{\mathbf{1}}^{*}-\mathbf{S}_{\mathbf{0}}^{*}\right\rangle \cdot \hat{\mathbf{c}}_{\mathbf{0}}\right)\right] \mathbf{u}\right\}+ \\
& \frac{1}{2}\left\{\widehat{\boldsymbol{\pi}}_{\mathbf{0}}^{-1} \mathbf{R}_{\mathbf{k} \mathbf{0}} \hat{\boldsymbol{l}}_{\mathbf{k} \mathbf{0}}^{*}\left[\mathbf{T}_{\mathbf{0}}^{*} \circ\left(\mathbf{S}_{\mathbf{0}}^{*} \cdot\left\langle\hat{\mathbf{c}}_{\mathbf{1}}-\hat{\mathbf{c}}_{\mathbf{0}}\right\rangle\right)\right] \mathbf{u}+\widehat{\boldsymbol{\pi}}_{\mathbf{1}}^{-1} \mathbf{R}_{\mathbf{k} \mathbf{1}} \hat{\boldsymbol{l}}_{\mathbf{k} \mathbf{1}}^{*}\left[\mathbf{T}_{\mathbf{1}}^{*} \circ\left(\mathbf{S}_{\mathbf{1}}^{*} \cdot\left\langle\hat{\mathbf{c}}_{\mathbf{1}}-\hat{\mathbf{c}}_{\mathbf{0}}\right\rangle\right)\right] \mathbf{u}\right\}
\end{aligned}
$$

To reiterate, we identified six determinants of changes between initial period 0 and final period 1 in the domestic demand for occupations $k$, related to changes within GVCs and the relative weights of these chains. We isolate the partial effects of these determinants, assuming that the other five partial effects were zero. It is important to note that structural decompositions are not unique as they change with the weights applied to the expressions. ${ }^{8}$ For that reason, we also compute its polar form (obtained by switching the initial and final year weights) and then take the average of the two. Dietzenbacher and Los (1998) argue this approach yields a close approximation to the average of the full set of possible decompositions.

Equation (6a) represents the changes in domestic demand for labor of occupation $k$ that can be attributed to productivity catch-up to the US (changes in efficiency or TFP). Equation (6b) gives the employment in occupation $k$ in the focal country-industry in the final year if only the intermediate

8 Dietzenbacher and Los (1998) show that if the number of components or determinants of a decomposition is $n$, then there are $n$ ! equivalent ways of writing the decomposition. 
demand shares of GVCs as captured by countries would have changed (changes in location-ofintermediate stages). In a similar vein, (6c) shows what would have happened if the only technological change within global supply chains would have been the only source of change (changes in GVC technology). Equation (6d) indicates what would have happened in the counterfactual case in which final demand shares of GVCs would have changed, but everything else would have remained stable (changes in location-of-completion). Equation (6e) isolates the effects of changes in consumption patterns (changes in consumption composition), while (6f) focuses on the effects of differential rates of consumption growth in the $G$ countries considered (changes in consumption levels). The changes regarding the composition and levels of consumption also include the effects of changing patterns and levels of investment demand. In our results, (6a) corresponds to 'country-level efficiency', (6c) to 'technology within GVC', the sum of (6b) and (6d) to 'task relocation,' (6e) to 'consumption composition,' which is the between GVC component in Figure 1, and (6f) to 'consumption levels.' Equation (6f) is further decomposed into 'own country' and 'rest of the world.'

\section{DATA}

The ADB MRIOTs provide data on $N=35$ industries and $G=48$ countries, including one that captures the 'rest of the world' (see Appendix, Tables A.1 and A.2 for the lists of economies and industries). Among the economies covered in the ADB MRIOTs are 12 economies in developing Asia: Bangladesh; India; Indonesia; Malaysia; Mongolia; the Philippines; the PRC; the Republic of Korea; Sri Lanka; Taipei,China; Thailand; Viet Nam. These economies have "developing member country" (DMC) status at ADB, although clearly there are substantial differences in levels of economic development between these economies. We used ADB MRIOTs for the years 2000, 2005, 2008, 2011, and 2015, deflated to 2000 prices to make sure that the relative magnitude of each component in our SDA is driven by changes in employment and output volumes, and not output prices. ${ }^{9}$

We expanded the MRIOTs to include occupational employment by country-industry. For Bangladesh; India; Indonesia; Malaysia; Mongolia; the Philippines; the Republic of Korea; Sri Lanka; Taipei,China; Thailand; and Viet Nam we used Labor Force Surveys, while the National Population Censuses of 2000 and 2010 provided occupational employment by industry data for the PRC. Throughout the analysis, we used 'persons employed' as the measure of employment and not 'hours worked,' because such data is not available for all economies in the dataset. If we do not have information for a certain year, then we interpolate or extrapolate the occupation-industry shares while making sure that the estimated shares always sum to 1 in each country-industry-year.

Because industry classifications vary from country to country, we first map national industry classifications to the 35 International Standard Industrial Classification revision 3.1 industries that allows us to merge the harmonized employment data with the MRIOTs and perform an SDA of the changes in occupational labor demand by country-industry.

The next step is to investigate how demand for specific types of jobs changes in response to technological advances along the value chain. We adopt the taxonomy developed in Autor, Levy, and Murnane (2003), which classifies occupations as routine manual, routine cognitive, nonroutine

9 The constant price series are constructed using the double deflation method, where gross value added is derived by deducting intermediate consumption in volume terms from total output in volume terms. Current values of gross industry outputs were all deflated using an appropriate price index (Paasche-type) which were all re-referenced to 2000 base prices $(2000=100)$. For final demand, aggregate deflators were implicitly derived (i.e., sum of final consumption by industry in volume terms). This method is the recommended approach in the System of National Accounts to estimating gross value added in volume terms (United Nations et al. 2009; see Ref. 15.2 of the report). 
manual, and nonroutine cognitive. However, there is substantial variation in national occupational classifications across countries, which again poses the problem of harmonization. The International Labour Organization developed the International Standard Classification of Occupations (ISCO), which provides an excellent basis for the international reporting, comparison, and exchange of data about occupations. Some of our micro datasets classified occupations using the older ISCO-88 version, in which case we converted them into the latest version, ISCO-08, using the correspondence tables provided by the International Labour Organization. Other countries, however, have national occupational classifications with structures that are quite different from ISCO. Where possible, we have used crosswalks from national industrial occupations to ISCO-08 as provided by statistical offices to guide our mapping.

Based on these restrictions, we select the occupation groups that allow us to have as much detail as possible while minimizing the amount of classification errors. The occupation groups are reported with the corresponding 2-digit ISCO-08 codes in Table 1 and classified as routine and nonroutine, manual and cognitive. After estimating employment shares by occupation-industry-year, we multiply the estimated shares with the number of persons employed by country-industry-year to obtain employment levels.

Table 1: Classification of Occupations

\begin{tabular}{lll}
\hline \multicolumn{1}{c}{ Routine } & \multicolumn{1}{c}{ Nonroutine } \\
\hline Manual & Craft and related trade workers [71-75] & Services and sales workers [51-54] \\
& Plant and machine operators and assemblers [81-83] & \\
& Elementary occupations [91-96] & \\
Cognitive & Clerical support workers [41-44] & Managers [11-14] \\
& & Professionals [21-26] \\
& & Technicians and associate professionals [31-35] \\
\hline
\end{tabular}

Notes: *Elementary occupations involve the performance of simple and routine tasks which may require the use of hand-held tools and considerable physical effort. The numbers in brackets refer to ISCO-08 codes, excluding Agriculture [61-63] and Armed forces [01-03]. The grouping of occupations in four categories (routine manual, routine cognitive, nonroutine manual, nonroutine cognitive) is based on Autor, Levy, and Murnane (2003), see Reijnders and de Vries (2018).

Source: Autor, Levy, and Murnane (2003).

As discussed in the previous section, we implement an efficiency correction using the countryyear TFP measures at constant national prices sourced from the Penn World Tables release 9.0 (Feenstra, Inklaar, and Timmer 2015). We normalize them by imposing the condition that TFP in the US in 2000 (corresponding to the base year of the constant price ADB MRIOTs) is equal to unity, so that country-level efficiency is pegged to a numeraire country at a fixed point in time.

The taxonomy developed by Autor, Levy, and Murnane (2003) to classify occupations as routine manual, routine cognitive, nonroutine manual, and nonroutine cognitive is not applicable to agricultural employment, since it is difficult to distinguish routine and nonroutine occupations in agriculture. As in Autor, Levy, and Murnane (2003) and subsequent work, agricultural occupations are not considered. In advanced countries, this is innocuous as agricultural occupations typically constitute a small fraction of the workforce (e.g., it is less than 4\% in the US, Autor [2015]). But in developing Asian countries this is a substantial part of total employment (see the final column in Appendix, Table A.3). The results presented in the next section pertain to the changes in labor demand associated with changes in consumption, trade, and technology on nonagricultural occupations. 


\section{RESULTS}

We perform structural decompositions at different levels of aggregation. First, we look at relative impacts of technology, task relocation, and consumption levels on changes on total employment by country and sector. Next, we split employment into the four occupational categories by sector. Finally, we look at the demand effects from domestic and foreign consumer expenditure.

Note that our analysis has two outliers: during 2005-2015, the global commodities bust hit hard in Mongolia, an economy heavily reliant on mining, causing a major decline in employment demand. The second outlier is Sri Lanka, where a 30-year civil war ended in 2009, followed by a period of record-breaking economic growth. This had a major effect on manufacturing employment and our results are less precise for these countries.

\section{A. Total Sectoral Employment}

The SDA for total sectoral employment by country is displayed in Table 2. Although we perform the SDA for all 48 MRIOT countries, we focus on analyzing results for the 12 developing Asian economies. Results for the other, mainly advanced, countries have been described in Reijnders and de Vries (2018). Columns (1)-(3) show employment levels in 2005 and 2015, and the percentage change in employment. Columns (4)-(9) contain the six terms of the decomposition: the within GVC channel (country-level efficiency, technology within GVC, and task relocation); the between GVC channel (consumption composition); and consumption levels (domestic demand for goods and services and demand for goods and services from the rest of the world). Table 2 is divided into three panels, displaying the SDA for (a) manufacturing, (b) services, and (c) all sectors.

Columns (1) to (3) document the structural transformation in developing Asia from the mid2000s to mid-2010. During this period, several Asian DMCs show faster growth in manufacturing employment compared to growth in employment in services. This is observed in Bangladesh, India, and Mongolia. Part of this growth in manufacturing employment might originate from an expansion of informal manufacturing firms (de Vries et al. 2012). But it may also originate from an expansion of GVC activities.

Indeed, column (6) documents that task relocation to Bangladesh and India positively contributed to demand for workers in manufacturing (accounting for $25 \%$ and $14 \%$ of the change, respectively). Our results suggest that many other Asian DMCs also benefited from the relocation of GVC tasks to their economies. What is apparent though, is that the effects of technological change (see columns [4] and [5]) account for a larger change in labor demand compared to task relocation.

The last columns of Table 2 compare the magnitude of changes in domestic employment levels associated with changes in consumption levels within the domestic economy, and for the rest of the world. Note the effects of own-country consumption levels are generally much larger than those from the rest of the world. In the PRC, for example, the increase in employment associated with owncountry consumption levels is $68 \%$ in manufacturing, and a staggering $105 \%$ in services, as opposed to $15 \%$, and $8 \%$ from the rest of the world. In addition, column ( 7 ) suggest a shift in the consumption composition toward manufactured goods and services. This is an encouraging sign that a new class of consumers has emerged from the Asian DMCs, generating domestic demand for products and services (we will examine this further in section V.C). Moreover, Table 2 shows that the increases in employment associated with own-country and rest-of-the-world consumption levels are large enough to offset the decrease in employment associated with GVC technology. 
Table 2: Structural Decomposition Analysis of the Changes in Employment by Sector, 2005-2015

\begin{tabular}{|c|c|c|c|c|c|c|c|c|c|}
\hline & \multirow[b]{2}{*}{$\begin{array}{c}\text { Employment } \\
\text { (2015) }\end{array}$} & \multirow[b]{2}{*}{$\begin{array}{l}\text { Employment } \\
(2005)\end{array}$} & \multirow[b]{2}{*}{$\begin{array}{c}\text { Change } \\
(\%)\end{array}$} & \multirow[b]{2}{*}{$\begin{array}{l}\text { Country-Level } \\
\text { Efficiency } \\
(\%)\end{array}$} & \multirow[b]{2}{*}{$\begin{array}{l}\text { Technology } \\
\text { within GVC } \\
(\%)\end{array}$} & \multirow[b]{2}{*}{$\begin{array}{c}\text { Task } \\
\text { Relocation } \\
(\%)\end{array}$} & \multirow[b]{2}{*}{$\begin{array}{c}\text { Consumption } \\
\text { Composition } \\
(\%)\end{array}$} & \multicolumn{2}{|c|}{ Consumption Levels } \\
\hline & & & & & & & & $\begin{array}{l}\text { Own } \\
\text { Country } \\
(\%)\end{array}$ & $\begin{array}{l}\text { Rest of } \\
\text { the World } \\
(\%)\end{array}$ \\
\hline \multicolumn{10}{|c|}{ A. Manufacturing ( $($ ) } \\
\hline Bangladesh & 8,595 & 5,200 & 65 & -10 & -61 & 25 & 31 & 67 & 13 \\
\hline China, People's Rep. of & 140,403 & 124,415 & 13 & -22 & -68 & 13 & 8 & 68 & 15 \\
\hline India & 72,633 & 54,486 & 33 & -23 & -50 & 14 & 14 & 66 & 12 \\
\hline Indonesia & 14,922 & 11,946 & 25 & -18 & -32 & 8 & 2 & 45 & 19 \\
\hline Korea, Rep. of & 4,847 & 4,234 & 14 & -9 & -36 & 14 & 3 & 12 & 30 \\
\hline Malaysia & 2,300 & 1,989 & 16 & -1 & -30 & -20 & 4 & 26 & 36 \\
\hline Mongolia & 81 & 46 & 78 & -68 & -13 & 4 & 39 & 95 & 22 \\
\hline Philippines & 3,209 & 3,077 & 4 & -21 & -29 & -13 & 3 & 50 & 14 \\
\hline Sri Lanka & 1,390 & 1,261 & 10 & -39 & -536 & 397 & 137 & 35 & 16 \\
\hline Taipei,China & 3,025 & 2,732 & 11 & -13 & -55 & 26 & 7 & 4 & 42 \\
\hline Thailand & 5,561 & 5,588 & 0 & -5 & -21 & -15 & 0 & 16 & 25 \\
\hline Viet Nam & 7,285 & 7,442 & -2 & -7 & -54 & -7 & 2 & 47 & 17 \\
\hline All Asian DMCs & 264,251 & 222,416 & 19 & -21 & -61 & 14 & 10 & 61 & 16 \\
\hline \multicolumn{10}{|c|}{ B. Services } \\
\hline Bangladesh & 20,617 & 16,358 & 26 & -8 & -22 & 3 & -31 & 79 & 7 \\
\hline China, People's Rep. of & 352,096 & 237,710 & 48 & -26 & -44 & 3 & 3 & 105 & 8 \\
\hline India & 135,997 & 115,329 & 18 & -22 & -32 & 0 & -13 & 78 & 6 \\
\hline Indonesia & 58,525 & 36,030 & 62 & -21 & -9 & 5 & 1 & 79 & 7 \\
\hline Korea, Rep. of & 17,545 & 14,879 & 18 & -9 & -6 & 2 & -3 & 23 & 11 \\
\hline Malaysia & 8,720 & 5,763 & 51 & -1 & -41 & -1 & 9 & 61 & 23 \\
\hline Mongolia & 590 & 419 & 41 & -58 & -36 & -185 & 208 & 100 & 12 \\
\hline Philippines & 21,452 & 15,074 & 42 & -25 & 76 & -44 & -47 & 75 & 7 \\
\hline
\end{tabular}




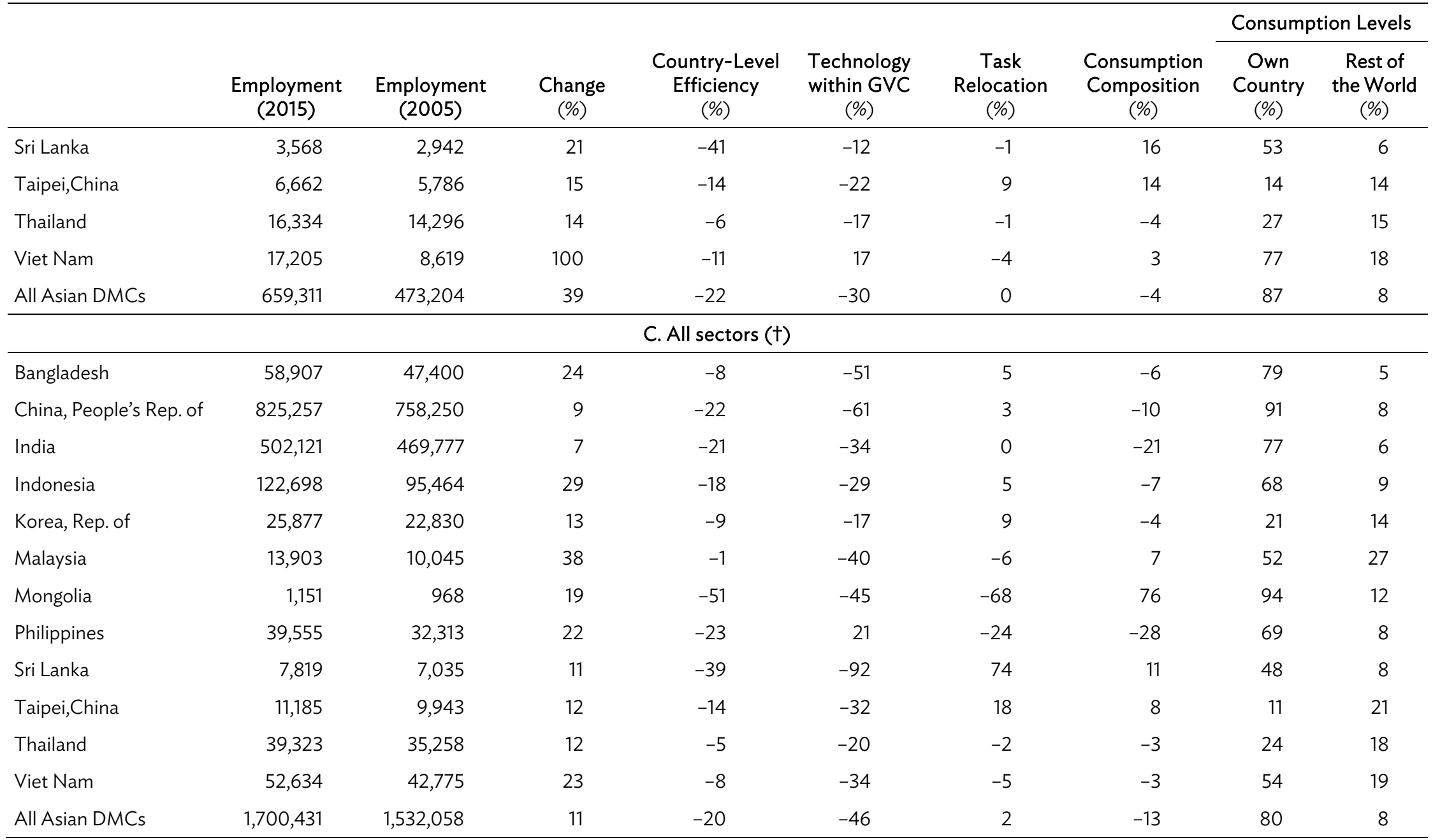

DMC = developing member country, GVC = global value chain

Note: (†)Manufacturing is derived by excluding 'Electricity, Gas and Water Supply' and 'Construction' from the industrial sectors. These are included in, 'C. All sectors'.

Source: Authors. 


\section{B. The Demand for Routine and Nonroutine Jobs}

Of great interest is whether certain occupations are more vulnerable than others to being displaced by technology. The results of the SDA by occupation type are presented for manufacturing in Table 3 and for services in Table 4. The overall trends are the same as in Table 2, but here the changes in employment are distributed across occupation types. In column (5), it can be observed that technology within GVC is associated with a decrease in employment across countries and occupation types, for both manufacturing and services. However, the decrease in nonroutine employment, especially nonroutine cognitive, is less pronounced than routine employment. In Bangladesh, the Philippines, and Viet Nam, there is even an increase in nonroutine employment in services. The findings suggest that technological advancements along the supply chain may have been skill biased during the period 2005-2015. This should not be surprising, since the introduction of modern machine tools and information and communication technology has been a feature of production for some time now.

In column (6), it can be observed that task relocation in manufacturing is also associated with an increase in nonroutine employment. In India, Indonesia, and the PRC, there is an increase in both nonroutine cognitive and nonroutine manual occupations; Bangladesh, Mongolia, and Thailand show an increase in nonroutine manual occupations, whereas Malaysia has an increase in nonroutine cognitive occupations. In services, if the outliers Mongolia and Philippines are excluded, the changes in employment are generally very small and mixed.

These changes affect the composition of employment. In general, the magnitude of the change in employment shares for manufacturing is relatively smaller and more uniform than services, which is characterized by more diverse dynamics. Technology within production chains is associated with an increase in the employment share of nonroutine cognitive occupations. For nonroutine manual occupations, roughly half the countries show an increase in employment shares, and the other half show a decrease. Finally, the change in employment shares for both routine cognitive and routine manual occupations associated with technological advancements is decidedly negative for manufacturing, and mainly negative for services. These results follow from Table 3 and Table 4, which show that, although technological advancements are generally associated with a reduction in both routine and nonroutine jobs conditional on their satisfying the same level of demand, the loss of routine jobs is larger. The changes in employment shares associated with task relocation are relatively small and mixed. 
Table 3: Structural Decomposition Analysis of the Change in Manufacturing Employment by Occupation Type, 2005-2015

\begin{tabular}{|c|c|c|c|c|c|c|c|c|c|}
\hline & \multirow[b]{2}{*}{$\begin{array}{c}\text { Employment } \\
\text { (2015) }\end{array}$} & \multirow[b]{2}{*}{$\begin{array}{l}\text { Employment } \\
\text { (2005) }\end{array}$} & \multirow[b]{2}{*}{$\begin{array}{c}\text { Change } \\
(\%)\end{array}$} & \multirow[b]{2}{*}{$\begin{array}{c}\text { Country-Level } \\
\text { Efficiency } \\
(\%)\end{array}$} & \multirow[b]{2}{*}{$\begin{array}{c}\text { Technology } \\
\text { within GVC } \\
(\%)\end{array}$} & \multirow[b]{2}{*}{$\begin{array}{c}\text { Task } \\
\text { Relocation } \\
(\%)\end{array}$} & \multirow[b]{2}{*}{$\begin{array}{c}\text { Task } \\
\text { Relocation } \\
(\%)\end{array}$} & \multicolumn{2}{|c|}{ Consumption Levels } \\
\hline & & & & & & & & $\begin{array}{l}\text { Own } \\
\text { Country } \\
(\%)\end{array}$ & $\begin{array}{l}\text { Rest of } \\
\text { the World } \\
(\%)\end{array}$ \\
\hline \multicolumn{10}{|c|}{ A. Nonroutine cognitive occupations } \\
\hline Bangladesh & 988 & 636 & 55 & -10 & -45 & -16 & 42 & 75 & 9 \\
\hline China, People's Rep. of & 21,637 & 17,569 & 23 & -23 & -59 & 8 & 10 & 74 & 14 \\
\hline India & 16,631 & 9,098 & 83 & -29 & -14 & 20 & 14 & 77 & 15 \\
\hline Indonesia & 1,227 & 583 & 110 & -25 & -3 & 51 & 2 & 60 & 26 \\
\hline Korea, Rep. of & 1,081 & 685 & 58 & -11 & -16 & 32 & 3 & 14 & 36 \\
\hline Malaysia & 716 & 361 & 98 & -1 & 3 & 11 & 5 & 35 & 46 \\
\hline Mongolia & 15 & 9 & 73 & -67 & -13 & -2 & 39 & 93 & 22 \\
\hline Philippines & 778 & 596 & 31 & -24 & -9 & -13 & 5 & 56 & 15 \\
\hline Sri Lanka & 121 & 150 & -19 & -32 & -564 & 381 & 150 & 31 & 15 \\
\hline Taipei,China & 1,005 & 819 & 23 & -14 & -40 & 22 & 7 & 4 & 44 \\
\hline Thailand & 852 & 1,041 & -18 & -5 & -21 & -31 & 0 & 15 & 24 \\
\hline Viet Nam & 802 & 859 & -7 & -7 & -43 & -23 & 0 & 51 & 16 \\
\hline All Asian DMCs & 45,854 & 32,406 & 41 & -23 & -43 & 12 & 11 & 68 & 17 \\
\hline \multicolumn{10}{|c|}{ B. Nonroutine manual occupations } \\
\hline Bangladesh & 617 & 496 & 25 & -8 & -101 & 3 & 50 & 74 & 6 \\
\hline China, People's Rep. of & 7,618 & 7,161 & 6 & -22 & -76 & 10 & 8 & 72 & 13 \\
\hline India & 2,515 & 1,541 & 63 & -27 & -37 & 23 & 14 & 78 & 12 \\
\hline Indonesia & 675 & 691 & -2 & -15 & -52 & 3 & 0 & 43 & 18 \\
\hline Korea, Rep. of & 197 & 194 & 2 & -9 & -49 & 16 & 3 & 11 & 30 \\
\hline
\end{tabular}




\begin{tabular}{|c|c|c|c|c|c|c|c|c|c|}
\hline & \multirow[b]{2}{*}{$\begin{array}{l}\text { Employment } \\
\text { (2015) }\end{array}$} & \multirow[b]{2}{*}{$\begin{array}{l}\text { Employment } \\
(2005)\end{array}$} & \multirow[b]{2}{*}{$\begin{array}{c}\text { Change } \\
(\%)\end{array}$} & \multirow[b]{2}{*}{$\begin{array}{l}\text { Country-Level } \\
\text { Efficiency } \\
(\%)\end{array}$} & \multirow[b]{2}{*}{$\begin{array}{l}\text { Technology } \\
\text { within GVC } \\
(\%)\end{array}$} & \multirow[b]{2}{*}{$\begin{array}{c}\text { Task } \\
\text { Relocation } \\
\text { (\%) }\end{array}$} & \multirow[b]{2}{*}{$\begin{array}{c}\text { Task } \\
\text { Relocation } \\
\text { (\%) }\end{array}$} & \multicolumn{2}{|c|}{ Consumption Levels } \\
\hline & & & & & & & & $\begin{array}{l}\text { Own } \\
\text { Country } \\
(\%)\end{array}$ & $\begin{array}{l}\text { Rest of } \\
\text { the World } \\
(\%)\end{array}$ \\
\hline Malaysia & 50 & 217 & -77 & 0 & -55 & -67 & 4 & 16 & 25 \\
\hline Mongolia & 5 & 2 & 137 & -85 & 22 & 25 & 41 & 108 & 25 \\
\hline Philippines & 53 & 50 & 6 & -21 & -37 & -11 & 5 & 61 & 9 \\
\hline Sri Lanka & 57 & 35 & 62 & -49 & -792 & 641 & 196 & 45 & 20 \\
\hline Taipei,China & 22 & 21 & 7 & -13 & -67 & 43 & 3 & 6 & 35 \\
\hline Thailand & 54 & 34 & 57 & -7 & -41 & 49 & 4 & 21 & 30 \\
\hline Viet Nam & 244 & 225 & 8 & -8 & -44 & -9 & 0 & 51 & 18 \\
\hline All Asian DMCs & 12,110 & 10,667 & 14 & -20 & -70 & 11 & 11 & 68 & 14 \\
\hline \multicolumn{10}{|c|}{ C. Routine cognitive occupations } \\
\hline Bangladesh & 145 & 124 & 17 & -8 & -112 & -1 & 61 & 69 & 8 \\
\hline China, People's Rep. of & 6,959 & 6,092 & 14 & -22 & -74 & 17 & 9 & 70 & 15 \\
\hline India & 1,376 & 1,233 & 12 & -21 & -63 & 6 & 10 & 69 & 11 \\
\hline Indonesia & 334 & 526 & -36 & -13 & -67 & -11 & 1 & 35 & 18 \\
\hline Korea, Rep. of & 883 & 851 & 4 & -9 & -38 & 6 & 3 & 12 & 30 \\
\hline Malaysia & 157 & 185 & -15 & -1 & -45 & -29 & 4 & 22 & 32 \\
\hline Mongolia & 2 & 1 & 100 & -74 & -8 & 20 & 40 & 100 & 23 \\
\hline Philippines & 185 & 187 & -1 & -20 & -41 & -9 & 3 & 51 & 13 \\
\hline Sri Lanka & 38 & 44 & -13 & -34 & -554 & 373 & 155 & 32 & 15 \\
\hline Taipei,China & 277 & 260 & 7 & -13 & -60 & 27 & 7 & 4 & 42 \\
\hline Thailand & 287 & 387 & -26 & -4 & -38 & -22 & 1 & 15 & 23 \\
\hline Viet Nam & 230 & 163 & 42 & -9 & -31 & 5 & 1 & 55 & 20 \\
\hline All Asian DMCs & 10,873 & 10,052 & 8 & -19 & -68 & 12 & 9 & 57 & 17 \\
\hline
\end{tabular}




\begin{tabular}{|c|c|c|c|c|c|c|c|c|c|}
\hline & \multirow[b]{2}{*}{$\begin{array}{l}\text { Employment } \\
\text { (2015) }\end{array}$} & \multirow[b]{2}{*}{$\begin{array}{l}\text { Employment } \\
\text { (2005) }\end{array}$} & \multirow[b]{2}{*}{$\begin{array}{c}\text { Change } \\
(\%)\end{array}$} & \multirow[b]{2}{*}{$\begin{array}{l}\text { Country-Level } \\
\text { Efficiency } \\
(\%)\end{array}$} & \multirow[b]{2}{*}{$\begin{array}{c}\text { Technology } \\
\text { within GVC } \\
(\%)\end{array}$} & \multirow[b]{2}{*}{$\begin{array}{c}\text { Task } \\
\text { Relocation } \\
(\%)\end{array}$} & \multirow[b]{2}{*}{$\begin{array}{c}\text { Task } \\
\text { Relocation } \\
(\%)\end{array}$} & \multicolumn{2}{|c|}{ Consumption Levels } \\
\hline & & & & & & & & $\begin{array}{c}\text { Own } \\
\text { Country } \\
(\%)\end{array}$ & $\begin{array}{c}\text { Rest of } \\
\text { the World } \\
(\%)\end{array}$ \\
\hline \multicolumn{10}{|c|}{ D. Routine manual occupations } \\
\hline Bangladesh & 6,845 & 3,945 & 74 & -10 & -57 & 36 & 26 & 64 & 14 \\
\hline China, People's Rep. of & 104,189 & 93,593 & 11 & -22 & -70 & 14 & 8 & 66 & 15 \\
\hline India & 52,111 & 42,615 & 22 & -22 & -58 & 13 & 15 & 63 & 12 \\
\hline Indonesia & 12,686 & 10,146 & 25 & -18 & -32 & 8 & 2 & 45 & 19 \\
\hline Korea, Rep. of & 2,685 & 2,504 & 7 & -9 & -41 & 12 & 4 & 12 & 29 \\
\hline Malaysia & 1,377 & 1,226 & 12 & -1 & -33 & -19 & 4 & 25 & 36 \\
\hline Mongolia & 59 & 34 & 75 & -67 & -17 & 4 & 39 & 94 & 22 \\
\hline Philippines & 2,193 & 2,243 & -2 & -20 & -33 & -13 & 2 & 49 & 14 \\
\hline Sri Lanka & 1,173 & 1,031 & 14 & -39 & -523 & 392 & 132 & 35 & 16 \\
\hline Taipei,China & 1,721 & 1,633 & 5 & -13 & -59 & 25 & 7 & 4 & 42 \\
\hline Thailand & 4,367 & 4,125 & 6 & -5 & -19 & -12 & 0 & 17 & 25 \\
\hline Viet Nam & 6,009 & 6,195 & -3 & -7 & -57 & -5 & 3 & 46 & 17 \\
\hline All Asian DMCs & 195,415 & 169,291 & 15 & -20 & -64 & 14 & 10 & 60 & 15 \\
\hline
\end{tabular}

DMC = developing member country, GVC = global value chain .

Source: Authors. 
Table 4: Structural Decomposition Analysis of the Change in Services Employment by Occupation Type, 2005-2015

\begin{tabular}{|c|c|c|c|c|c|c|c|c|c|}
\hline & \multirow[b]{2}{*}{$\begin{array}{l}\text { Employment } \\
\text { (2015) }\end{array}$} & \multirow[b]{2}{*}{$\begin{array}{l}\text { Employment } \\
(2005)\end{array}$} & \multirow[b]{2}{*}{$\begin{array}{c}\text { Change } \\
(\%)\end{array}$} & \multirow[b]{2}{*}{$\begin{array}{l}\text { Country-Level } \\
\text { Efficiency } \\
(\%)\end{array}$} & \multirow[b]{2}{*}{$\begin{array}{c}\text { Technology } \\
\text { within GVC } \\
(\%)\end{array}$} & \multirow[b]{2}{*}{$\begin{array}{c}\text { Task } \\
\text { Relocation } \\
\text { (\%) }\end{array}$} & \multirow[b]{2}{*}{$\begin{array}{c}\text { Consumption } \\
\text { Composition } \\
(\%)\end{array}$} & \multicolumn{2}{|c|}{ Consumption Levels } \\
\hline & & & & & & & & $\begin{array}{c}\text { Own } \\
\text { Country } \\
(\%)\end{array}$ & $\begin{array}{l}\text { Rest of } \\
\text { the World } \\
(\%)\end{array}$ \\
\hline \multicolumn{10}{|c|}{ A. Nonroutine cognitive occupations } \\
\hline Bangladesh & 5,621 & 2,278 & 147 & -13 & 56 & 5 & -19 & 112 & 6 \\
\hline China, People's Rep. of & 155,905 & 103,169 & 51 & -27 & -30 & 5 & -11 & 105 & 9 \\
\hline India & 86,934 & 64,560 & 35 & -24 & -19 & 3 & -15 & 83 & 6 \\
\hline Indonesia & 32,917 & 18,635 & 77 & -22 & 1 & 6 & 1 & 84 & 7 \\
\hline Korea, Rep. of & 7,456 & 6,596 & 13 & -9 & -5 & -3 & -3 & 23 & 10 \\
\hline Malaysia & 2,384 & 1,629 & 46 & -1 & -33 & -5 & 0 & 63 & 21 \\
\hline Mongolia & 206 & 159 & 29 & -54 & -22 & -72 & 64 & 106 & 8 \\
\hline Philippines & 8,797 & 6,793 & 29 & -24 & 66 & -44 & -49 & 75 & 6 \\
\hline Sri Lanka & 1,350 & 1,187 & 14 & -39 & -9 & -4 & 8 & 54 & 4 \\
\hline Taipei,China & 3,780 & 3,249 & 16 & -14 & -23 & 11 & 14 & 14 & 15 \\
\hline Thailand & 5,257 & 4,616 & 14 & -6 & -25 & -7 & 10 & 29 & 12 \\
\hline Viet Nam & 5,450 & 2,590 & 110 & -12 & 5 & -4 & 18 & 88 & 14 \\
\hline All Asian DMCs & 316,056 & 215,463 & 47 & -24 & -19 & 2 & -11 & 90 & 8 \\
\hline \multicolumn{10}{|c|}{ B. Nonroutine manual occupations } \\
\hline Bangladesh & 6,120 & 6,132 & 0 & -7 & -34 & -1 & -37 & 71 & 7 \\
\hline China, People's Rep. of & 132,466 & 91,566 & 45 & -26 & -60 & 2 & 17 & 103 & 8 \\
\hline India & 26,442 & 35,062 & -25 & -17 & -61 & -7 & -12 & 67 & 7 \\
\hline Indonesia & 9,396 & 9,557 & -2 & -15 & -55 & -2 & 1 & 62 & 7 \\
\hline Korea, Rep. of & 5,953 & 4,843 & 23 & -10 & -6 & 6 & -3 & 23 & 12 \\
\hline
\end{tabular}




\begin{tabular}{|c|c|c|c|c|c|c|c|c|c|}
\hline & \multirow[b]{2}{*}{$\begin{array}{l}\text { Employment } \\
\text { (2015) }\end{array}$} & \multirow[b]{2}{*}{$\begin{array}{c}\text { Employment } \\
\text { (2005) }\end{array}$} & \multirow[b]{2}{*}{$\begin{array}{c}\text { Change } \\
(\%)\end{array}$} & \multirow[b]{2}{*}{$\begin{array}{c}\text { Country-Level } \\
\text { Efficiency } \\
(\%)\end{array}$} & \multirow[b]{2}{*}{$\begin{array}{c}\text { Technology } \\
\text { within GVC } \\
(\%)\end{array}$} & \multirow[b]{2}{*}{$\begin{array}{c}\text { Task } \\
\text { Relocation } \\
(\%)\end{array}$} & \multirow[b]{2}{*}{$\begin{array}{c}\text { Consumption } \\
\text { Composition } \\
(\%)\end{array}$} & \multicolumn{2}{|c|}{ Consumption Levels } \\
\hline & & & & & & & & $\begin{array}{l}\text { Own } \\
\text { Country } \\
(\%)\end{array}$ & $\begin{array}{l}\text { Rest of } \\
\text { the World } \\
\text { (\%) }\end{array}$ \\
\hline Malaysia & 2,892 & 1,699 & 70 & -1 & -38 & 8 & 11 & 66 & 23 \\
\hline Mongolia & 199 & 142 & 40 & -57 & -60 & -354 & 402 & 95 & 14 \\
\hline Philippines & 4,208 & 2,351 & 79 & -29 & 224 & -104 & -100 & 76 & 11 \\
\hline Sri Lanka & 854 & 599 & 43 & -45 & -12 & 6 & 30 & 54 & 9 \\
\hline Taipei,China & 1,267 & 1,026 & 23 & -14 & -16 & 4 & 24 & 15 & 11 \\
\hline Thailand & 4,078 & 3,914 & 4 & -5 & -5 & 3 & -29 & 25 & 14 \\
\hline Viet Nam & 7,961 & 1,776 & 348 & -21 & 191 & 44 & -14 & 111 & 37 \\
\hline All Asian DMCs & 201,836 & 158,668 & 27 & -21 & -48 & -2 & 4 & 86 & 8 \\
\hline \multicolumn{10}{|c|}{ C. Routine cognitive occupations } \\
\hline Bangladesh & 1,042 & 1,817 & -43 & -6 & -88 & -2 & -15 & 64 & 5 \\
\hline China, People's Rep. of & 22,683 & 19,115 & 19 & -23 & -50 & 2 & -18 & 101 & 6 \\
\hline India & 6,871 & 6,328 & 9 & -21 & -54 & 2 & 0 & 75 & 6 \\
\hline Indonesia & 4,210 & 3,490 & 21 & -17 & -54 & -1 & 16 & 73 & 4 \\
\hline Korea, Rep. of & 3,037 & 2,528 & 20 & -9 & -9 & 5 & -2 & 22 & 13 \\
\hline Malaysia & 1,383 & 1,118 & 24 & -1 & -52 & -15 & 14 & 56 & 21 \\
\hline Mongolia & 32 & 15 & 107 & -76 & 6 & -65 & 111 & 114 & 17 \\
\hline Philippines & 4,430 & 2,511 & 76 & -29 & 7 & 8 & -1 & 83 & 8 \\
\hline Sri Lanka & 328 & 320 & 2 & -37 & -20 & 0 & 4 & 51 & 5 \\
\hline Taipei,China & 1,023 & 928 & 10 & -13 & -20 & 9 & 8 & 14 & 12 \\
\hline Thailand & 2,535 & 1,733 & 46 & -6 & -16 & 5 & 17 & 30 & 17 \\
\hline Viet Nam & 956 & 497 & 92 & -11 & -2 & -3 & 13 & 80 & 16 \\
\hline All Asian DMCs & 48,530 & 40,400 & 20 & -19 & -43 & 2 & -7 & 80 & 8 \\
\hline
\end{tabular}




\begin{tabular}{|c|c|c|c|c|c|c|c|c|c|}
\hline & \multirow[b]{2}{*}{$\begin{array}{l}\text { Employment } \\
\text { (2015) }\end{array}$} & \multirow[b]{2}{*}{$\begin{array}{l}\text { Employment } \\
\text { (2005) }\end{array}$} & \multirow[b]{2}{*}{$\begin{array}{c}\text { Change } \\
(\%)\end{array}$} & \multirow[b]{2}{*}{$\begin{array}{c}\text { Country-Level } \\
\text { Efficiency } \\
(\%)\end{array}$} & \multirow[b]{2}{*}{$\begin{array}{c}\text { Technology } \\
\text { within GVC } \\
(\%)\end{array}$} & \multirow[b]{2}{*}{$\begin{array}{c}\text { Task } \\
\text { Relocation } \\
(\%)\end{array}$} & \multirow[b]{2}{*}{$\begin{array}{c}\text { Consumption } \\
\text { Composition } \\
(\%)\end{array}$} & \multicolumn{2}{|c|}{ Consumption Levels } \\
\hline & & & & & & & & $\begin{array}{l}\text { Own } \\
\text { Country } \\
(\%)\end{array}$ & $\begin{array}{l}\text { Rest of } \\
\text { the World } \\
(\%)\end{array}$ \\
\hline \multicolumn{10}{|c|}{ D. Routine manual occupations } \\
\hline Bangladesh & 7,834 & 6,130 & 28 & -9 & -21 & 8 & -36 & 78 & 7 \\
\hline China, People's Rep. of & 41,041 & 23,860 & 72 & -29 & -43 & 0 & 25 & 112 & 8 \\
\hline India & 15,750 & 9,378 & 68 & -27 & 2 & 9 & -12 & 89 & 8 \\
\hline Indonesia & 12,002 & 4,348 & 176 & -30 & 82 & 21 & -9 & 102 & 11 \\
\hline Korea, Rep. of & 1,099 & 912 & 20 & -9 & -5 & 5 & -6 & 22 & 14 \\
\hline Malaysia & 2,061 & 1,317 & 57 & -1 & -41 & 2 & 13 & 57 & 27 \\
\hline Mongolia & 153 & 102 & 50 & -60 & -34 & -144 & 176 & 97 & 15 \\
\hline Philippines & 4,017 & 3,418 & 18 & -22 & 43 & -40 & -39 & 68 & 8 \\
\hline Sri Lanka & 1,037 & 835 & 24 & -41 & -11 & -4 & 22 & 52 & 7 \\
\hline Taipei,China & 592 & 583 & 1 & -13 & -28 & 9 & 6 & 12 & 15 \\
\hline Thailand & 4,464 & 4,032 & 11 & -5 & -18 & -3 & -4 & 25 & 17 \\
\hline Viet Nam & 2,839 & 3,756 & -24 & -7 & -58 & -24 & -2 & 54 & 12 \\
\hline All Asian DMCs & 92,890 & 58,672 & 58 & -22 & -17 & 0 & 2 & 87 & 9 \\
\hline
\end{tabular}

$\mathrm{DMC}$ = developing member country, GVC = global value chain.

Source: Authors. 


\section{Foreign versus Domestic Expenditure and Labor Demand}

The evidence thus far indicates that technological change within GVC is generally associated with a decrease in employment across all occupation types, although routine occupations are relatively more affected. Production technologies such as industrial robots have been used for decades, but they are now becoming increasingly flexible and cheaper.

Developing economies that have benefited from offshoring of production tasks from advanced economies are now concerned about 'reshoring'; that is, they fear that it could become economically feasible to move those production tasks back to the country of origin. In an SDA, reshoring would appear as a sizable decrease in employment associated with task relocation. Indeed, the fact that it is not the case in the period 2005-2015 does not necessarily imply that it won't change in the near future.

To determine whether employment in Asian developing countries is becoming increasingly less dependent on final demand from advanced economies, the approach adopted by Los, Timmer, and de Vries (2015) is utilized. Figure 3 shows the change in the number of jobs induced by final demand in the period 2005-2015 as a fraction of total jobs. It is decomposed into domestic final demand, final demand from advanced economies, and final demand from the rest of the world. ${ }^{10}$

Figure 3 shows that domestic final demand is associated with an $11 \%$ increase in employment for the 12 Asian DMCs as a whole. Taipei,China is the only economy that shows a decrease in employment associated with domestic final demand, whereas Malaysia (at 35\%) and the Philippines (at 24\%) show the largest increases. This is consistent with the rebalancing away from a manufacturing and export-led growth model, to services and consumption-led model.

Jobs induced by final demand from advanced economies have decreased by $1 \%$ for the 12 DMCs together. Negative demand effects due to the global financial crisis and subsequent slow growth in final demand in advanced countries are likely affecting the results, especially for the PRC. Viet $\mathrm{Nam}$ is the economy where final demand from advanced countries was the most important source of increased job demand (11\%), followed by Taipei,China (6\%), and the Republic of Korea (4\%). What all three economies have in common is rapid technological change, which implies that less workers are needed to satisfy the same level of demand.

The key advantage of reshoring is to move production close to the customers, resulting in shorter time to market, lower production costs, and increased efficiency." While consumer markets in advanced economies are increasingly saturated, earlier in this section, reference was made to the expanding Asian middle class and its rising demand for goods and services. Perhaps the most interesting observation from Figure 1 is that, although the increase in employment associated with final demand from the rest of the world is only $1 \%$ for all 12 DMCs together, it is quite large for economies like Malaysia (11\%); Taipei,China (10\%); and Thailand (9\%). Markets in the 'rest of the world' have a high potential for growth, and therefore the relative importance of final demand from advanced countries for employment in developing countries will likely decline over time.

10 The 'advanced economies' in this decomposition are Australia, Austria, Belgium, Canada, Denmark, Finland, France, Germany, Greece, Ireland, Italy, Japan, Luxembourg, the Netherlands, Portugal, Spain, Sweden, the United Kingdom, and the US. For each of the 12 DMCs in the chart, the 'rest of the world' category includes the other 11, as well as other economies at various stages of development.

${ }^{11}$ 'Time to market' is the time it takes from a product being conceived until its being available for sale. 
Figure 3: Changes in the Number of Jobs Induced by Foreign and Domestic Demand, 2005-2015

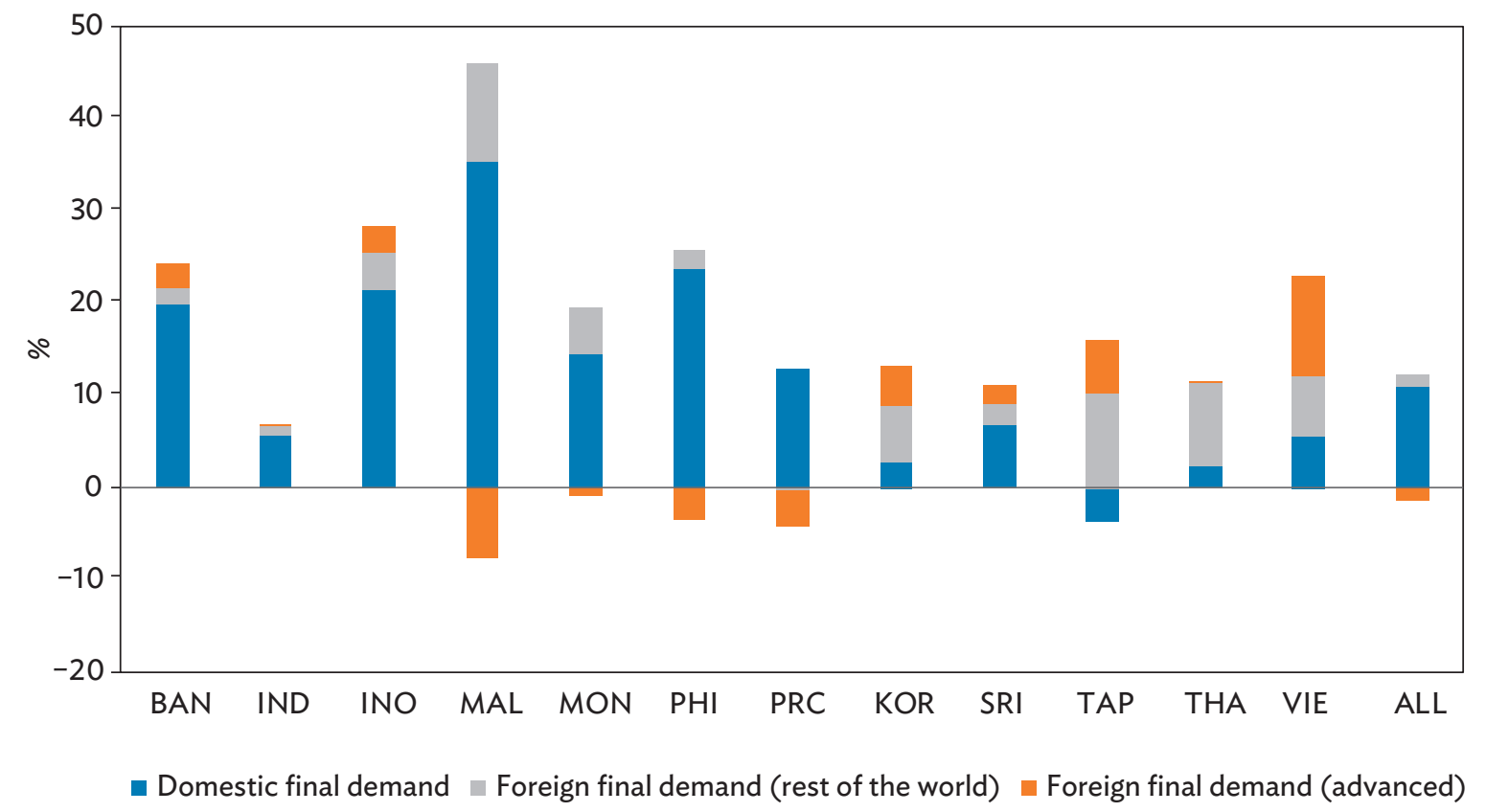

BAN = Bangladesh; IND = India; INO = Indonesia; $K O R=$ Republic of Korea; $M A L=$ Malaysia; $M O N=$ Mongolia; $P R C=$ People's Republic of China; $\mathrm{PHI}=$ Philippines; $\mathrm{SRI}=$ Sri Lanka; TAP = Taipei,China; THA = Thailand; $\mathrm{VIE}=$ Viet Nam; ALL = 12 developing Asian economies.

Source: ADB estimates using data from ADB Multiregional Input-Output Database (accessed 20 November 2017), Labor Force Surveys, and Socioeconomic Accounts of the World Input-Output Database (accessed 30 August 2017).

\section{CONCLUSION}

In many countries around the world, labor markets have seen a rise in nonroutine cognitive and nonroutine manual occupations relative to routine task-intensive occupations. So far, analysis of this phenomenon has been restricted to advanced and a select set of emerging countries. In this paper we have expanded coverage to developing countries by studying changes in the job structure in developing Asian countries.

We have examined these job structure changes through the lens of a GVC framework. In particular, for each supply chain we look at changes in the use of occupational labor per dollar of output (defined as 'technology within GVCs') and shifts in the share captured by each country ('task relocation'). Our findings suggest that technological change within GVCs tends to drive down the demand for routine relative to low- and high-wage nonroutine jobs. However, the emergence of a consuming middle class and thereby the increases in employment demand associated with owncountry increased expenditures are large enough to offset the decrease in employment associated with GVC technology.

These findings are based on a decomposition that is essentially an ex post accounting exercise. The results are useful empirical findings, but we cannot claim to have determined a causal effect nor have isolated specific mechanisms for the observed changes in the structure of employment. In 
practice, technological change and task relocation are interrelated. For example, an improvement in information technology may reduce labor demand throughout a supply chain, but it may also affect the ease at which a task can be relocated.

We believe the occupation-based analysis presented in this paper opens up important avenues for future research that may uncover causal mechanisms. In particular, the measurement of occupations involved in GVCs provides a novel angle to study the effects of robot adoption on employment changes. The use of robots by lead firms in advanced countries may affect the demand for workers in developing countries participating in the value chain of the lead firm. An example is the use of robots in "speedfactories" built by Adidas in Germany and the US. In essence, textile workers in developing countries are being replaced by robots in advanced countries. The scale and significance of these employment changes has not been examined yet.

Researchers may also use the approach put forth here and develop the data to examine the drivers of changes in the job structure in other developing countries, notably in Africa and Latin America. Finally, a critical open research question is the extent to which the occupational employment shifts documented here are helpful for understanding changes in wage inequality. 


\section{APPENDIX}

Table A.1: The 48 Multiregional Input-Output Table Economies

\begin{tabular}{|c|c|}
\hline Australia & Luxembourg \\
\hline Austria & Malta \\
\hline Belgium & Mexico \\
\hline Brazil & Netherlands \\
\hline Bulgaria & Poland \\
\hline Canada & Portugal \\
\hline China, People's Republic of & Romania \\
\hline Cyprus & Russian Federation \\
\hline Czech Republic & Slovak Republic \\
\hline Denmark & Slovenia \\
\hline Estonia & Spain \\
\hline Finland & Sweden \\
\hline France & Taipei,China \\
\hline Germany & Turkey \\
\hline Greece & United Kingdom \\
\hline Hungary & United States \\
\hline India & Bangladesh \\
\hline Indonesia & Malaysia \\
\hline Ireland & Philippines \\
\hline Italy & Thailand \\
\hline Japan & Viet Nam \\
\hline Korea, Republic of & Mongolia \\
\hline Latvia & Sri Lanka \\
\hline Lithuania & Rest of the world (ROW) \\
\hline
\end{tabular}

Source: Authors. 
Table A.2: The 35 Multiregional Input-Output Table Industries

\begin{tabular}{|c|c|}
\hline ISIC 3.1 Code & Description \\
\hline AtB & Agriculture, hunting, forestry and fishing \\
\hline C & Mining and quarrying \\
\hline $15 \mathrm{t} 16$ & Food, beverages and tobacco \\
\hline $17 \mathrm{t} 18$ & Textiles and textile products \\
\hline 19 & Leather, leather and footwear \\
\hline 20 & Wood and products of wood and cork \\
\hline $21 \mathrm{t} 22$ & Pulp, paper, printing and publishing \\
\hline 23 & Coke, refined petroleum and nuclear fuel \\
\hline 24 & Chemicals and chemical products \\
\hline 25 & Rubber and plastics \\
\hline 26 & Other nonmetallic minerals \\
\hline $27 \mathrm{t} 28$ & Basic metals and fabricated metals \\
\hline 29 & Machinery, nec \\
\hline $30 t 33$ & Electrical and optical equipment \\
\hline $34 \mathrm{t} 35$ & Transport equipment \\
\hline $36 \mathrm{t} 37$ & Manufacturing, nec; recycling \\
\hline $\mathrm{E}$ & Electricity, gas and water supply \\
\hline $\mathrm{F}$ & Construction \\
\hline 50 & Sale, maintenance and repair of motor vehicles and motorcycles; retail sale of fuel \\
\hline 51 & Wholesale trade and commission trade, except of motor vehicles and motorcycles \\
\hline 52 & Retail trade, except of motor vehicles and motorcycles; repair of household goods \\
\hline $\mathrm{H}$ & Hotels and restaurants \\
\hline 60 & Inland transport \\
\hline 61 & Water transport \\
\hline 62 & Other supporting and auxiliary transport activities; activities of travel agencies \\
\hline 63 & Air transport \\
\hline 64 & Post and telecommunications \\
\hline $\mathrm{J}$ & Financial intermediation \\
\hline 70 & Real estate activities \\
\hline $71 \mathrm{t} 74$ & Renting of machinery and equipment and other business activities \\
\hline $\mathrm{L}$ & Public administration and defense; compulsory social security \\
\hline M & Education \\
\hline $\mathrm{N}$ & Health and social work \\
\hline $\mathrm{O}$ & Other community, social and personal services \\
\hline$P$ & Private households with employed persons \\
\hline
\end{tabular}

nec $=$ not elsewhere classified.

Source: Authors. 
Table A.3: Sources of Occupational Employment Data

\begin{tabular}{|c|c|c|c|c|}
\hline & Source of Occupational Employment Data & $\begin{array}{c}\text { Original } \\
\text { Occupational } \\
\text { Classification }\end{array}$ & $\begin{array}{l}\text { Mapped } 8 \\
\text { Occupations } \\
\text { (\% of non- } \\
\text { agricultural } \\
\text { employment) }\end{array}$ & $\begin{array}{l}\text { Mapped } 8 \\
\text { Occupations } \\
\text { (\% of total } \\
\text { employment) }\end{array}$ \\
\hline \multirow[t]{2}{*}{ Bangladesh } & Labour Force Survey 2005-2006 & ISCO-88 & 99.16 & 66.26 \\
\hline & Quarterly Labour Force Survey 2015-2016 & ISCO-08 & 98.38 & 63.18 \\
\hline \multirow{2}{*}{$\begin{array}{l}\text { China, People's } \\
\text { Rep. of }\end{array}$} & Population Census 2000 & SOC & 99.83 & 54.89 \\
\hline & Population Census 2010 & SOC & 99.83 & 63.91 \\
\hline \multirow[t]{2}{*}{ India } & National Sample Survey 2004-2006 & $\mathrm{NCO}-04$ & 100.00 & 42.90 \\
\hline & National Sample Survey 2008 & NCO-04 & 100.00 & 48.15 \\
\hline \multirow[t]{2}{*}{ Indonesia } & National Labor Force Survey (Sakernas), 2005 & KBJI-02 & 100.00 & 53.89 \\
\hline & National Labor Force Survey (Sakernas), 2010 & KBJI-02 & 100.00 & 61.79 \\
\hline \multirow[t]{2}{*}{ Korea, Rep. of } & Korea Labor and Income Panel Study (KLIPS) 2005 & KSCO & 100.00 & 92.25 \\
\hline & Korea Labor and Income Panel Study (KLIPS) 2010 & KSCO & 100.00 & 93.08 \\
\hline \multirow[t]{2}{*}{ Malaysia } & Labor Force Survey 2009 & ISCO-88 & 98.55 & 88.49 \\
\hline & Labor Force Survey 2015 & ISCO-88 & 99.92 & 93.32 \\
\hline \multirow[t]{2}{*}{ Mongolia } & Labor Force Survey 2002 & ISCO-08 & 99.23 & 54.55 \\
\hline & Labor Force Survey 2015 & ISCO-08 & 99.76 & 71.59 \\
\hline \multirow[t]{2}{*}{ Philippines } & Labor Force Survey 2004 & 1992 PSOC & 99.46 & 80.87 \\
\hline & Labor Force Survey 2015 & 1992 PSOC & 99.65 & 86.41 \\
\hline \multirow[t]{2}{*}{ Sri Lanka } & Labor Force Survey 2004 & ISCO-88 & 98.55 & 78.74 \\
\hline & Labor Force Survey 2014 & ISCO-08 & 98.53 & 79.39 \\
\hline \multirow[t]{2}{*}{ Taipei,China } & Manpower Survey 2005 & ISCO-88 & 100.00 & 94.19 \\
\hline & Manpower Survey 2010 & ISCO-88 & 100.00 & 94.84 \\
\hline \multirow[t]{2}{*}{ Thailand } & Labor Force Survey 2005 & ISCO-88 & 99.36 & 61.87 \\
\hline & Labor Force Survey 2010 & ISCO-88 & 99.35 & 61.89 \\
\hline \multirow[t]{2}{*}{ Viet Nam } & Labor Force Survey 2007 & ISCO-88 & 95.82 & 94.33 \\
\hline & Labor Force Survey 2013 & ISCO-08 & 96.17 & 85.98 \\
\hline
\end{tabular}

$\mathrm{KBJI}=$ Klasifikasi Baku Jabatan Indonesia, $\mathrm{KSCO}=$ Korea Standard Classification of Occupations, NCO = National Classification of Occupations, PSOC = Philippine Standard Occupation Classification.

Notes: Time series employment data are used to estimate occupational employment shares. Only presented here are sources of employment data that are closest to 2005 or 2015.

Source: Authors. 


\section{REFERENCES}

Acemoglu, Daron, and Pascual Restrepo. 2017. "Robots and Jobs: Evidence from US Labor Markets." National Bureau of Economic Research (NBER) Working Paper No. 23285.

Arntz, Melanie, Terry Gregory, and Ulrich Zierahn. 2016. "The Risk of Automation for Jobs in OECD Countries: A Comparative Analysis.” OECD Social, Employment and Migration Working Paper No. 189. Paris: OECD Publishing.

Asian Development Bank (ADB). 2017. Asian Economic Integration Report 2017: The Era of Financial Interconnectedness. Manila.

2018. Asian Development Outlook 2018. How Technology Affects Jobs. Manila.

Autor, David. 2013. “The 'Task Approach' to Labor Markets: An Overview.” Journal of Labour Market Research 46 (3): 185-99.

2015. "Why Are There Still So Many Jobs? The History and Future of Workplace Automation." Journal of Economic Perspectives 29 (3): 3-30.

Autor, David H., David Dorn, and Gordon H. Hanson. 2016. "The China Shock: Learning from LaborMarket Adjustment to Large Changes in Trade." Annual Review of Economics 8: 205-40.

Autor, David, Frank Levy, and Richard Murnane. 2003. "The Skill Content of Recent Technological Change: An Empirical Exploration.” Quarterly Journal of Economics 118 (4): 1279-333.

Autor, David, and Anna Salomons. 2017. “Does Productivity Growth Threaten Employment?” Working paper.

Chang, Jae-Hee, and Phu Huynh. 2016. ASEAN in Transformation: The Future of Jobs at Risk of Automation. Geneva: International Labour Organization.

Chun, Natalie, and Heiwai Tang. 2018. "Do Information and Communication Technologies Empower Female Workers? Firm-Level Evidence from Viet Nam.” ADB Economics Working Paper Series No. 545.

Citi and Oxford Martin School. 2016. Technology at Work v2.0: The Future Is Not What It Used to Be. Citigroup.

De Backer, Koen, Carlo Menon, Isabelle Desnoyers-James, and Lauernt Moussiegt. 2016. "Reshoring: Myth or Reality?" OECD Science, Technology and Industry Policy Paper No. 27.

de Vries, Gaaitzen J., Quanrun Chen, Rana Hasan, and Zhigang Li. 2016. "Skills and Activity Upgrading in Global Value Chains: Trends and Drivers for Asia." ADB Economics Working Paper Series No. 496.

de Vries, Gaaitzen J., Abdul Azeez Erumban, Marcel P. Timmer, llya Voskoboynikov, and Harry X. Wu. 2012. "Deconstructing the BRICs: Structural Transformation and Aggregate Productivity Growth."Journal of Comparative Economics 40 (2): 211-27. 
Defever, Fabrice. 2012. "The Spatial Organization of Multinational Firms." Canadian Journal of Economics 45 (2): 672-97.

Dietzenbacher, Erik, and Bart Los. 1998. "Structural Decomposition Techniques: Sense and Sensitivity." Economic Systems Research 10 (4): 307-24.

Feenstra, Robert C., Robert Inklaar, and Marcel P. Timmer. 2015. "The Next Generation of the Penn World Table." American Economic Review 105 (10): 3150-82.

Frey, Carl Benedikt, and Michael A. Osborne. 2017. "The Future of Employment: How Susceptible Are Jobs to Computerisation?” Technological Forecasting and Social Change 114: 254-80.

Goos, Maarten, Alan Manning, and Anna Salomons. 2014. "Explaining Job Polarization: Routine-Biased Technological Change and Offshoring." American Economic Review 104 (8): 2509-26.

Graetz, Georg, and Guy Michaels. 2018. “Robots at Work.” Working paper.

Leontief, Wassily W. 1936 "Quantitative Input and Output Relations in the Economic Systems of the United States." The Review of Economics and Statistics 18 (3): 105-25.

Los, Bart, Marcel Timmer, and Gaaitzen J. de Vries. 2014. "The Demand for Skills 1995-2008: A Global Supply Chain Perspective.” OECD Economics Department Working Paper No. 1141.

- 2015. "How Important Are Exports for Job Growth in China? A Demand Side Analysis." Journal of Comparative Economics 43 (1): 19-32.

McKinsey Global Institute (MGI). 2017. A Future that Works: Automation, Employment, and Productivity. McKinsey \& Company.

Michaels, Guy, Ashwini Natraj, and John Van Reenen. 2014. "Has ICT Polarized Skill Demand? Evidence from Eleven Countries over 25 Years." Review of Economics and Statistics 96 (1): 60-77.

Miller, Ronald, and Peter Blair. 2009. Input-Output Analysis: Foundations and Extensions. 2nd ed. Cambridge University Press.

Reijnders, Laurie S. M., and Gaaitzen J. de Vries. 2018. "Trade, Technology and the Rise of NonRoutine Jobs.” Journal of Development Economics 135: 412-32.

Reijnders, Laurie S., Marcel P. Timmer, and Xianjia Ye. 2016. "Offshoring, Biased Technical Change and Labor Demand: New Evidence from Global Value Chains." Groningen Growth and Development Centre Research Memorandum No. 164.

Stewart, Ian, Debapratim De, and Alex Cole. 2015. Technology and People: The Great Job-Creating Machine. London: Deloitte LLP.

Timmer, Marcel P., Abdul Azeez Erumban, Bart Los, Robert Stehrer, and Gaaitzen J. de Vries. 2014. "Slicing Up Global Value Chains." Journal of Economic Perspectives 28 (2): 99-118. 
United Nations Economic and Social Commission for Asia and the Pacific (UNESCAP). 2015. "Global Value Chains and Interconnectedness of Asia-Pacific Economies." In Asia-Pacific Trade and Investment Report 2015: Supporting Participation in Value Chains. Bangkok.

United Nations, European Commission, International Monetary Fund, Organisation for Economic Cooperation and Development, and World Bank. 2009. System of National Accounts 2008. New York: United Nations. 


\section{The Employment Effects of Technological Innovation, Consumption, and Participation in Global Value Chains: Evidence from Developing Asia}

This paper examines how employment responded to consumption, trade, and technological advances in developing Asia during the period 2005-2015. Global value chains have helped create jobs in developing countries in Asia, but there is concern that technology could displace workers. The study uses a demandbased input-output approach to explore this concern. Its findings indicate that technological change in global value chains was associated with a decrease in labor demand across all sectors, and an increase in the share of nonroutine cognitive occupations. Further, higher domestic consumption increased labor demand enough to offset the negative impact of technological change.

\section{About the Asian Development Bank}

ADB is committed to achieving a prosperous, inclusive, resilient, and sustainable Asia and the Pacific, while sustaining its efforts to eradicate extreme poverty. Established in 1966, it is owned by 67 members48 from the region. Its main instruments for helping its developing member countries are policy dialogue, loans, equity investments, guarantees, grants, and technical assistance. 